【論 文】

UDC : 72.032.6\%.7
日本建築学会計画系論文報告集 第 411 号・1990 年 5 月 Journal of Archit. Plann. Environ. Engng, AIJ, No.411, May, 1990

\title{
パルテノン神殿の設計手順 \\ DESIGN PROCEDURE OF THE PARTHENON
}

\author{
五島利兵衛* \\ Rihee GOSHIMA
}

\begin{abstract}
This study employs the grid method to examine the design procedure used in the Temple of Parthenon (built 447-432.B. C). The grid method is a new point of view : it has recently been applied in analyzing the design by J. J. Coulton, R. Tobin and K. Horiuchi. This study started by regarding the grid in round number 15 doric feet proposed by Horiuchi as a 1 st plan grid $(7 \times 15$ units) and the grid in intercolumnar units proposed by Coulton as a 2 nd plan grid ( $8 \times 18$ units, each unit measures $131 / 8$ doric feet). Both grids were also employed to analyze the facade design.
\end{abstract}

Keywords : design procedure, grid method, grid symmetry

\section{序}

本研究は，グリッド法にもとづいてパルテノン神殿 （前 447-432）の設計手順について考察したものである。 グリッド法とは碁盤目状の図形を用いた設計方法のこ とで，その設計手順とは，グリッドからグリッドを派生 させながら順を追って設計することで，その手順は，現 場で施工する際の作業手順とも対応している出。

パルテノン神殿は, アテネのアクロポリスに位置し, 前面 8 柱・側面 17 柱のドリス式周柱神殿で, 守護神ア テナを祀ったものである。規模的には基壇矩形 $30.88 \mathrm{~m}$ $\times 69.60 \mathrm{~m}$, 柱高 $10.43 \mathrm{~m}$ の大神殿である。建設工事は, フェイディアスの総監督のもとにイクティノス，カリク ラテスが設計施工しだ洋。

ギリシア人の一族ドーリア人がバルカン半島に定着し たのは前 12 世紀であった。この時期から前 9 世紀まで は「暗黒時代」であった。ミュケーネのメガロンを範と して神殿をつくり始めたのは前 9 世紀頃で，周囲に円柱 をめぐらした周柱形式を採用したのは前 8７ 世紀頃で ある(文)。柱が軒を支える構造形式を建築美として追求 する造形方法は, 古拙期 (前 7,6 世紀), 古典期 (前 5,4 世 紀）を通じて一貫した。そして，建築を構成する基壇， 柱, 梁 (エンタブラチュア), 切妻屋根 (ペディメント) の各部分，及び全体を美的にするために，寸法計画を比 例と調和の法則に従わしめた。比例と調和という考え方 は, 当時の自然科学や哲学, 宇宙秩序の考え方と結びつ いていた壮4。造形的には，神像を理想的人間像として 制作する美術的方法と軌を一つにしていたせ5)。ローマ
時代の建築家ヴィトルヴィウ.スは書築書（前 50 年頃） を著わし、「神殿の構成はシュムメトリアから定まる ……。これはギリシア語でアナロギアという比例から得 られる……シュムメトリアまたは比例を除外しては，す なわち，容姿の立派な人間に似るように各肢体が正確に 割付けられているのでなければ，いかなる神殿も構成の 手段をもちえない」と述べているま6。

ギリシア人にとって美とは調和（シュムメトリア又は シンメトリー) であり, それは比例の法則によって達成 されると考えた。古典期にギリシア本土，ペロポネンス および南イタリア，シシリーでは数多くのドリス式周柱 神殿が，比例の法則にもとづいてつくられた。その造形 美の頂点に立つのがパルテノンである。後にギリシア神 殿は古典建築と呼ばれ，その造形理念はヨーロッバ建築 の根本を形づくった。しかし，比例法則の全容は未だ明 らかではない。

パルテノンその他ギリシア神殿建築について多くの考 古学的調查や実測が行われ，比例に関する研究は今日ま で数多くなされている。だが，その成果について，ディ ンズムアが「ギリシア神殿，特にパルテノン神殿の平面 を，一連の同心円・同心正方形; 5 角形又は星形 5 角 形; 6 角形又は星形 6 角形（正三角を 2 つ逆さに重ねた もの); 8 角形; 10 角形; 门回転正方形】; 黄金分割」な どのようなやや複雑な幾何学から導こうとする現代の多 くの試みには，その論拠に一言警告をせ㸚ばならないで あろう」洋》と述べているように，「今なお，満足な方法 は得られていない。把8

本論文の一部は注 14 の曺及び本学会大会梗概「バルテノン神殷の設計手順」（H．1１0）において既に発表したものである。 
こうした中で, 近年パルテノンを含むドリス式周柱神 殿の設計法に関してグリッド法という新しい方法論が展 開されている。それは J. J. クールトン, R. トビン, 堀内清治の 3 者による研究である蚯)。クールトンの研 究について、トビンは「ドリス式神殿設計を合理的に解 明する重要なステップである」と述べているぜ10)。クー ルトンは，提案される設計方法が実際に使われたかどう かは, その方法が簡単であること, 遺構の実測值に一致 すること, 同じ地域・時代の一群の建物に共通すること の 3 つの判断基準で測られるとしている"11)。上記 3 者 の研究は,このような基準のもとに実測値から設計方法 を復原することを課題としているが, その場合, クール トンは基壇比（基壇上面の正面幅と奥行の比）に，トビ ンはギリシア数学の平面数望 221 , 堀内は完数尺単位に 注目した。そして，いずれも平面設計に限定されるがグ リッドを採用している。グリッドは設計施工上最も簡単 で, 分りやすいだけでなく, 遺構の柱や柱間数と対応し, 当時のモデュールの考え方とも一致しているき13)。

ギリシア神殿の設計には平面設計だけに限定しても, 柱間寸法が先か基壇寸法が先かという決定順序の問題, 同じく, 神室が先か周柱が先かという問題, 更に, 基壇 比の実現法, 隅柱間の短縮法などの問題がある。クール トンやトビンはこれらの問題を解決する方法として, 最 初に柱間単位のグリッドが設定され, 次にそのグリッド 寸法を修正して柱間や基壇の大きさが決定されたと考え た。グリッドの設定は最初の一回だけである。

堀内は, パルテノンの設計手順の研究で, 平面グリッ ドの単位が間であるという考えを捨て，1単位(これ を $M$ と略記） 15 尺の完数尺で, $7 M \times 15 M$ の平面グ リッドから設計がスタートしたと説いた㳯14堀内もクー ルトン，トビンと同じくグリッドの設定は一回だけであ る。本研究は,グリッドの設定は一回に限定せず，堀内 の提案を第 1 の平面グリッド，そしてクールトン，トビ ンの柱間単位のグリッドを第 2 の平面グリッドと考える ことから出発している。堀内においてグリッドは実側寸 法すなわち施工寸法とは直接関わってこない。その意味 でグリッドは設計法上非本質的である。しかし，本研究 ではグリッドが設計施工寸法を決定する方法であり本質 的役割をもっている。そのグリッドは単一のものではな く, 複数のグリッドからなり, グリッドの単位,・グリッ ドの派生 (分割・倍数),グリッドの組み合わせなどが 設計法上の検討課題である。そしてこの派生関係や組み 合わせも調和の法則にもとついていると考える゙士15)。

グリッドによる設計方法を推定復原する場合，当然な がら推定寸法値が実測值と一致しなければならない。本 研究は, この点でディンズムアや堀内ら先学が提示した ドリス尺で表現された設計施工寸法を踏襲し，その寸法 值と完全に一致することを考察の基準とした。そのドリ
ス尺寸法値を示すと次の通りである。 主要各部寸法进16)

1 尺 $=0.3275 \mathrm{~m}$ ，実測値はペンローズによる， $1 \mathrm{ft}=0.3048 \mathrm{~m}$ 推定寸法値 実测値誤差

身廊内法幅 $=30$ 尺 $=9.825 \mathrm{~m} \quad 9.825 \mathrm{~m} \quad 0.000 \mathrm{~m}$ 標準柱間 $I=13 \frac{1}{8}$ 尺 $=4.298 \mathrm{~m} \quad 4.297 \mathrm{~m}$ (東·平均) $0.001 \mathrm{~m}$ 隅柱間 $I_{A}=11 \frac{1}{4}$ 尺 $=3.684 \mathrm{~m} \quad 3.668 \mathrm{~m}$ (東北隅) $0.016 \mathrm{~m}$ 柱径 $D=5 \frac{5}{6}$ 尺 $=1.910 \mathrm{~m} \quad 1.903 \mathrm{~m}$ (東 ·平均) $0.007 \mathrm{~m}$ 柱高 $H=31 \frac{7}{8}$ 尺 $=10.439 \mathrm{~m} \quad 10.430 \mathrm{~m} \quad-0.009 \mathrm{~m}$ 基壇幅 $W=94 \frac{1}{2}$ 尺 $=30.949 \mathrm{~m} \quad 30.889 \mathrm{~m}$ (東) $\quad 0.060 \mathrm{~m}$ 基壇奥行 $L=212 \frac{5}{8}$ 尺 $=69.635 \mathrm{~m} 69.541 \mathrm{~m}$ (北) $\quad 0.094 \mathrm{~m}$ $O W=103 \frac{1}{8}$ 尺 $=33.773 \mathrm{~m}$ $O L=221 \frac{1}{4}$ 尺 $=72.459 \mathrm{~m}$ $P W=88 \frac{1}{8}$ 尺 $=28.861 \mathrm{~m}$ $P L=206 \frac{1}{4}$ 尺 $=67.547 \mathrm{~m} \quad$ （記号は注 44 参照） エンタブラチュア高 $=42$ 尺 $=13.755 \mathrm{~m}$

本研究で,グリッド法の出発点が身廊内法幅（スタイ ロベート内法間) の 30 尺という解釈にあり，この点か ら 1 ドリス尺 $=0.3275 \mathrm{~m}$ という堀内説を採用するとと もにペンローズの実測値を上記以外の実測值においても 利用したせ17)。

上記のドリス尺寸法値の中で, ディンズムアと堀内の 尺寸法値が異なっている $W, L, I_{A}$ についてディンズム アのものを採用した。それは, 両者とも許容誤差内にあ るが淁18), クールトンの平面公式 $W=I_{W}\left(N_{K^{\prime}}+\frac{1}{5}\right)$, $L=I_{L}\left(N_{L}+\frac{1}{5}\right)$ 及び筆者の双正方形の適用による $I_{A}=\frac{6}{7}$ $I$ の式に合致するからである゙19\}。また， $W, L$ につい てディンズムアの尺寸法は 4 対 9 の比例でできているか らである。

本研究は先ず，パルテノン神殿の設計法に関する研究 之問題点を述べる(第 1 章)。この中で特にグリッド法 に関するクールトン, トビン, 堀内の研究について詳墖 する。これらの研究はドリス式周柱神殿の設計法として 考察されているのでそのような視点から論ずる。次いで, 本稿のテーマであるパルテノン神殿の設計手順について 図解しながら諭ずる。この設計手順を第 2 章とした。第 3 章でまとめた。

本研究の目次は次の通りである。

1. パルテノン神殿の設計法に閵する研究と問題点

(1) 数学的比例法

（2）幾何学的比例法

(3) グリッド法

(1) クールトンの平面公式 
(2) トビンの平面数

(3) 堀内の平面グリッド

(4) 本研究のグリッド法：グリッド・シンメトリー

2. グリッド法にもとづくパルテノン神殿の設計手順

(1) 神室平面の設計手順

(2) 平面の設計手順

（3）立面の設計手順

3. 結び

1. パルテンン神殿の設計法に関する研究と問題点

パルテノン神殿の設計法の研究史の詳細な考察は別の 機会に変り，重要な研究を歴史的に列挙すると次の通り である。

(1) 1751-54 年 2 人のイギリス人リヴェットとス チュアートによる調査 ${ }^{2201}$

初めての科学的調查, その後の設計法研究の出 発点となる。

(2) 1840-47 年 ペンローズによる実測調查裙11

前記の調査をより完全なものにした。此例の指 摘, 曲線の原理の発見。その後の比例法研究の科 学的資料として活用される。

(3) 1857 年 ワトキス・ロイドの数学的比例理論き22)

5 の差でつくられた比例 $(1: 6,2: 7,3: 8$, $4: 9,5: 10$ など) と 1 の差でっくられた比例 $(1$ $: 2,2: 3,3: 4,4: 5$ など) で設計されたと説 $<$ 。

(4) 1924 年 ハンビッジのダイナミック・シンメト リー $¥ 23)$

神殿正面は 4 つの正方形と $6 \supset$ つ $\sqrt{5}$ 矩形で構 成して設計されたと説く。

(5) 1925 年 R.W. ガードナーの $\sqrt{5}$ の比例理論 ${ }^{ \pm 24}$

柱頭成 $\rightarrow$ 柱径 $\rightarrow$ 柱間 $\rightarrow$ 柱身 $\rightarrow$ 神室幅 $\rightarrow$ 神室 奥行は，柱頭成を 1 としてこれに $\sqrt{5}$ を次々と乗 じて設計されたと説く。

(6) 1950 年 ディンズムアの 4 対 9 の比例の重視㠵25)

基壇比, 柱径・柱間比，オーダー総高・基壇幅 比が同一の 4 対 9 の比例は偶然ではなく, 検討す ベき内容であると説く。

(7) 1974 年 クールトンの平面公式き26)

パルテノンの平面は, $W: L=C_{w}:\left(C_{L}+1\right)$; $W=I_{W}\left(N_{W}+\frac{1}{5}\right), \quad L=I_{L}\left(N_{L}+\frac{1}{5}\right)$ の公式により設 計された，と説く。W : 基壇幅， $L$ : 基壇奥行， $C_{w}, C_{L}$ : 柱数 ( $W$ は正面, $L$ は側面), $I_{W}, I_{L}$ : 柱間（同）, $N_{w}, N_{L}$ : 柱間数 (同)。

(8) 1988 年 堀内の平面グリッドせ27)

パルテノンの平面は, $1 M=15$ 尺とすると, 7 $M \times 15 M$ のグリッドより出発して設計されたと 説く。
以上を設計方法論として分類すると（1）数学的比例

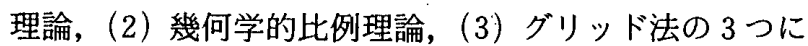
分類できる。これらの方法論の特徵, 問題点について以 下検討する部8)。

(1) 数学的比例理論

L.D. カスケイは，パルテノン神殿の比例法に関す る研究について次のように述べている。

「文献記録がないので（比例システムが各寸法に合致 しているかぼうか）究極の疑問には答えられない。パル テノンの建築家が数学的比例を使って設計したかどうか さえわからない。仮りに，その比例を使うたとしてもそ れを再発見する手がかりもない。ヴィトルヴィウスの諸 規則は，ギリシア建築の実際の比例を反映していると言 われるが，5世紀以後のイオニアの建築でさえ正確に適 合していない。ドリス式周柱神殿には明らかに当てはま らない。この問題を解決する唯一の方法は, 現存する建 物に色々な設計システムを適用し，適合度の強さを判定 することである。

過去に多くの試みがなされたが，その結果は残念なが ら著者の思い違いである。これまでの分析方法には2つ ある。1つは, ワトキス・ロイドによるパルテノンの比 例の研究であり, もう1つは幾何学的なもので, その代 表的なものはハンビッジのダイナミック・シンメトリー による比例理論である」这29)

ワトキス・ロイドの比例理論の要旨は次の通りであ る。

「パルテノンは, 厳密な比例で施工された。その比例は, $1: 6,2: 7,3: 8,4: 9,5: 10$ など $5 つ$ 差の比例関 係と，4:5，5:6，6:7などの 1 の差の比例が用いら れた。比例には同一又は平行する直線内での直線的比例 と，直交関係にある長方形比例の 2 種類がある。上記の 比例は，ある時は直線的比例として，ある時は長方形比 例として用いられた。」き30)

ワトキス・ロイドの比例理論についてカスケイは,

「彼は，この比例に合致するいくつかの例をあげてい るが，彼の理論はほとんど顧りみられなかった。不完全 な調查が支持を得られなかったのである。また，円柱高 と隅柱のアバクス幅は $1: 5$ などにみられるようにこの ような数列に属さない比例が実際に使われている。パル テノン神殿の基壇比 4 対 9 .は簡単な比であるが，ロイド の理論では，その比の美学的重要性や設計実務上の有用 性は明らかではない。」き311 と述べている。最後の「美学 的重要性」とは八ンビッジのダイナミック・シンメト リーの意義を念頭においている言葉である。基壇比の 4 対 9 などその後理論的考察の上で重要な指摘を含んでい る。更に重要なことは比例の数列はギリシア数学の平面 数の理論と結びつくことである゙ ${ }^{\sharp 22) 。 ~}$ 


\section{（2）幾何学的比例}

1924 年, ハンビッジは, パルテノンは「ダイナミック・ シンメトリ」と命名される比例理論にもとづいて設計さ れていると主張した。ハンビッジの主張は，口イドの数 学的比例理論に対して幾何学的比例理論を示している。

幾何学的比例理論についてカスケイは次のように述べ ている。

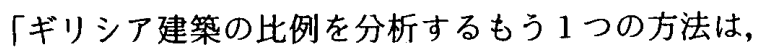
幾何学的なもので……これは描き方で一致性が変ってく るので……正確な数值的資料にもとづかない限り意味が ない。」

そして，ハンビッジのダイナミック・シンメトリにつ いて次のように述べている。

ハンビッジは，ギリシア人は数学的であると同時に幾 何学的であるシンメトリを知っていたということを喚起 したのである。ルート矩形が使われていたことはプラト

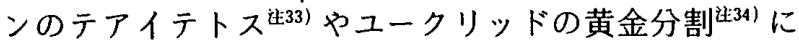
よって知ることができる。

「ハンビッジの理論に対して, 芸術家は数学者ではな い,ダイナミック・シンメトリーはギリシアの職人には 理解できない，イクティノスのような建築家にさえ実施 できない，などの批判がある。しかし，幾何学は土地測 量法から漸次発展してきたもので，ハンビッジによるパ ルテノンの比例は直角をつくる方法と同じように簡単に 杭と縄で施工できる。

唯一, 彼の理論への批判は, 比例が無理数であるとい うことである。それは, 万物がそのような調和 (analysed in accordance with it) をもっているということである。 そして，今まで不明であったことは，正方形から簡単に 求められる ( $\sqrt{5}$ 矩形, その逆数, 黄金比な民゙) わずか の無理数比を繰り返し利用している点である。」き35)

カスケイは，ハシンビッジの説について「ペンローズの 実測值が正しいと仮定するならばユークッド幾何学に よって証明されたとしなければならないであろう」゙36)と しながらも，今後の検討に付す問題として次の点をあげ ている。

「(1)この理論は, 前 5 世紀のギリシア人に知られてい た数学的比例と一致するか。

(2) これらの原理は, 数学者と同様芸術家にも理解さ れるほど簡単であるのか。幾何図形は定規とコンパス, あるいは地面上での杭とロープで，そして数学的計算 なしで作り得たか。

(3) 幾 10 尺，幾 100 尺として実測されているパルテ ノンの最も重要な寸法がこれらの幾何図形と正確に一 致するのか。

(4)これらの幾何図形の採用は, 設計を実施する実際 的助けとなっているのか。

(5)このような設計システムの利用は，パルテノンの
至高の特性と讃えられる比例と調和をつくりだす上で 奇与しているか」非37)

以上, カスケイの主張で特徵や問題点は言い尽されて いる。カスケイの主張の中で数学的比例との関係が問題 点として指摘されているが， R. カーペンターは，ギリ シアつぼに関してであるが, ダイナミック・シンメトリ の比は，スタティック・シンメトリの比とほとんど変ら ず, $\sqrt{5}$ は 4 対 9 に, $\sqrt{3}$ は 4 対 7 に, 黄金比 1.618 は 5 対 8 に, 黄金比系列の 1.309 は 3 対 4 に置換できるこ とを明らかにしている゙は38\%。

ハンビッジの理論が公刊された翌年の 1925 年, R.W. ガードナーが $\sqrt{5}$ の連続比例論を発表している。すなわ ち, パルテノン神殿は, 柱頭成を 1 として, 柱径, 柱間, 柱身, 神室外法幅, 神室外法奥行は $\sqrt{5}$ を次々と乗じた 寸法で設計されたというき"399。

柱頭成を $a$, 柱径を $b$, 柱間を $c$, 柱身を $d$, 神室外 法幅を $e$, 神室外法奥行を $f$ とする。 $a$ は実測値 $0.8589 \mathrm{~m}$ (以下, すべてペンローズによる。フィート をメートルに換算）で, $b=\sqrt{5} a=1.9206 \mathrm{~m}$ (実測値 $1.905 \mathrm{~m}$ ), $c=5 a=4.2945 \mathrm{~m}$ (実測值 $4.2968 \mathrm{~m}$ ),$d=$ $5 \sqrt{5} a=9.6028 \mathrm{~m}$ (実測値 $9.58 \mathrm{~m}$ ), $e=25 a=21.4725$ $\mathrm{m}$ (実測值 $21.484 \mathrm{~m}$ ), $f=25 \sqrt{5} a=48.0140 \mathrm{~m}$ (実測 值 $48.349 \mathrm{~m}$ ) である。以上で $f$ のみが $30 \mathrm{~cm}$ 以上の誤 差をもち，他はすべて実測值と一致している。eに対し て 4 対 9 の比を用いると $f=21.4725 \times \frac{9}{4}=48.313 \mathrm{~m}$ で 実測値と一致する。

ガードナーの説は比の連続性という点で興味深いが, 柱頭成が出発点ではなく柱間（これを $I$ と略記）を出 発点として前後に連続したと考えた方が合理的である。 そして，カーペンターが指摘するように $\sqrt{5}$ は 4 対 9 の 比に置き換えることができる。このようにしてガード ナ一の説を練り直してみると次のようである。柱間 $I=$ $4.2968 \mathrm{~m}$ である。柱径 $=\frac{4}{9} I=1.91 \mathrm{~m}$ (実測值 $1.905 \mathrm{~m}$ ), 柱身 $=\frac{9}{4} I=9.668 \mathrm{~m}$ (実測值 $9.58 \mathrm{~m}$ ), 神室奥行 $=5 \times$ $\frac{9}{4} I=48.339$ (実測値 $48.349 \mathrm{~m}$ ) である。柱頭成 $=\frac{1}{5} I$ $=0.8597 \mathrm{~m}$ （実測値 $0.8589 \mathrm{~m}$ ), 神室幅 $=5 I=9.612 \mathrm{~m}$ (実測値 $9.58 \mathrm{~m}$ ) である。この中で柱身については $\sqrt{5}$ の比例（柱身 $=\sqrt{5} I=9.608 \mathrm{~m} ）$ が実測值に対して正確 であるが, 他の寸法では 4 対 9 の比例の方が実測值に一 致している。

ガードナーの説で残念なことは, 基壇比の 4 対 9 , 正 面比(基壇上面よりコーニス上端までと基壇幅の比)の 4 対 9 が，上記の連続比例と結びついていないことである。 ガードナーの説について, 滝沢真弓は, ハンビッジ説 への批判を行ないながら次のように評価している(一部 要約・構成・かなづかいも現代風に修正)。

「混沌たるパルテノン論の渦中にあって1つの期を画 した人はハンビッジである。彼はパルテノン研究の上に 
方法論的方向を提示した。彼はギリシア語のシンメトリ アを『面積で割り合う」(平方して共約的となる) とい う意味で洞察し，これを『ダイナミック・シンメトリ」 と命名した。しかし，彼は， $\sqrt{3}, \sqrt{5} \cdots \cdots$ などの無理数 をそのまま利用し，平方してシンメトリアとすることを なしえなかった。

同国人のガードナーは, 平方してシンメトリアになる ことを示した。パルテノンの構図問題についての最後の 功績は少くとも今日までの所ではこの 2 人のアメリカ人 に帰せられねばならない迷40

(3) グリッド法

ここで述べるグリッド法は施工する立場からの比例法

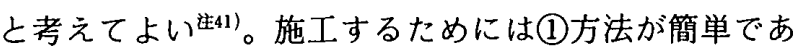
ること, (2)その方法によって正確に造ることができるこ とが条件である。その上で(3)その方法によって目的とす る美しい形態が造れることである。更に，現代の我々が 設計法を研究する場合，クールトンの言うように，その 時代や地域における普遍的方法であることを念頭におか ねばならない。グリッド法は先ず(1),(2)の条件を満足さ せている茫42)。(3)の条件の満足は後述する。

グリッド法による設計法の研究はクールトンに始ま り,トビン, 堀内へ之継承・発展させられている。これ ら 3 者の研究内容について検討してみよう。

(1) クールトンの平面公式

クールトンは基壇比 $(W: L)$ と柱数比 $\left(C_{W}: C_{L}\right)$ との関係を考察し，次の 3 つに類型化される平面公式が 採用されていることを明らかにした注43)。ここで及び本 稿で使用する記号の意味は注 44 にまとめた。クールト ンの公式は表によった。そのため, 第 2 公式中の $W$ : $L=\left(C_{w}+1\right):\left(C_{L}+1\right)$ は削除した。神殿の全棟数は 49 棟で，そのうち公式の成立している棟数を（）内に示 した。公式は神殿によって $2 つ ， 3$ つ同時に成立してい るので，（）内棟数合計は 49 棟を上回る。

1）第 1 公式（初期本土式）

$$
\begin{aligned}
& W: L=C_{W}: C_{L} \\
& O W: O L=C_{W}: C_{L}
\end{aligned}
$$

2）第 2 公式 (シシリリー式)

$$
\begin{aligned}
& W: L=C_{W}:\left(C_{L}+1\right) \\
& W: L=C_{W}:\left(C_{L}+2\right) \\
& W: L=\left(C_{W}+1\right):\left(C_{L}+\frac{1}{2}\right)
\end{aligned}
$$

3）第 3 公式 (後期本土式)

$$
W=I\left(N_{w}+\frac{1}{3}\right), \quad L=I\left(N_{L}+\frac{1}{3}\right)
$$

常数 $\frac{1}{3}$ は, その他に, $\frac{3}{10}$ ( 7 棟), $\frac{1}{4}$ (6 棟), $\frac{3}{8}$ (3 棟), $\frac{1}{5}, \frac{1}{2}, \frac{3}{16}, \frac{7}{16}$ (各 1 棟) がある。これらの常数を総称し て $k$ とおく。

この 3 つの公式は, 基壇比型（W: $L$ と $O W: O L$ を含む）と柱間型（第 3 公式）の 2 つに分類してその設
計法上の特徵と問題点を考察する。

a) 基壇比型の設計手順と問題点

基壇比型では柱数 $C_{w}, C_{L}$ が最初に決定され，これに 対応する等間隔柱間（I）一想定という意味で（）を つける一が想定されて基壇規模 $W, L$ が決定される。 この基壇を柱数 $C_{w}, C_{L}$ で分割して柱間 $I_{w}, I_{L}$ が決定さ れる。ここで，何故等間隔柱間が想定されるかというと 正面柱間 $I_{W}$ と側面柱間 $I_{L}$ は異なっているからである。 実際例で 43 棟中（このうち 6 棟は $I_{L}$ が欠けている）， 17 棟（このうち 1 棟は片側側面のみ一致）が一致し，2 $\sim 3 \mathrm{~cm}$ 以内で一致しているのは 8 棟, 残り 24 棟は誤差 が大きく, $10 \mathrm{~cm}$ 以上異なるのはこのうち 13 棟もある。 そこで上記設計手順は，等間隔柱間と実際の柱間とを 2 回設定しているので,

$$
\begin{gathered}
C_{w}, C_{L} \underset{\uparrow}{\longrightarrow} W, L \underset{\uparrow}{\longrightarrow} \text { 実際の柱間 } I_{W}, I_{L} \\
\text { 等間隔柱間 }(I) \quad \text { 柱数 } C_{w}, C_{L} \text { で分割 }
\end{gathered}
$$
（隅柱間の短縮を含む）

と図式化できる。

この手順の特徵は，等間隔柱間 $(I)$ のグリッドが柱 数に対応して最初に設定され，このグリッド輪郭矩形が 基壇規模を決定する。そして，そのグリッドを構成する 円柱は移動され，柱間は変更されたと考えるところにあ

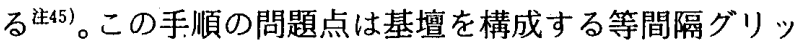
ドは円柱の移動によって消失するので，等間隔グリッド は想定の域を出ず，設計手順の段階で存在したという確 証はないことである。これを（I）の問題という。

b）柱間型の設計手順之問題点

クールトンは, 前 5 世紀初め頃から柱間を先に決定す る方法を採用したと言う。をの設計手順は，

$$
C_{w}, C_{L} \longrightarrow\left(\begin{array}{l}
\text { 第 } 3 \text { 公式 }) \\
(N, L
\end{array}\right.
$$

と図式化できる洋46) この手順で $k I$ は基壇規模決定に 関わっている。そのため, 逆に隅柱の位置の決定法が不 明で，「その場の成りゆき ad hoc」き47) まかせで隅柱の位 置を決めるという問題をもっている。

$k I$ の問題は先の基壇比型の場合でも言えることで, 更に, 基壇比型と柱間型の両方が成り立つ神殿では設計 手順は更に複雑になる。クールトンは「比例法則の適用 方法は未だ多く不明で，おおよその原理が確認される程 度である」 ${ }^{ \pm 48)} と$ 述べている。

以下, トビン, 堀内は, クールトンの残した $(I)$ と $k I$ の問題によ゙う対応したか, という視点でみてゆくこ とができる。

(2) トビンの平面数娄49\}

トビンは, クールトンの想定等間隔柱間 $(I)$ を $X$ と して， $C_{w}$ を $a, C_{L}$ を $b$ として表記して $(a \times b) \cdot X$ を 設計の出発点とする。これは, クールトンの等間隔柱間 グリッドそのものであるが，これをギリシア数学の平面 
数の適用と解釈し, そこから算術的に $W, L ; P W, P L$

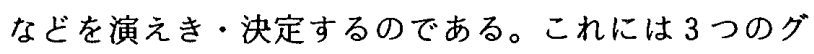
ループに分けられる注50)。

第 1 のグループ (列柱拡大型) の設計手順 オリンピア・ヘラ神殿の例, 柱数 $6 \times 16$

$$
a \times b=6 \times 16 \longrightarrow+\uparrow \times L=6 \times 16
$$

$X$ を 1 単位とする

$\uparrow$ $P W \cdot P L=5 \times 15, \quad X=3.129 \mathrm{~m}$

两項 1 減算

㬰測值との対応から $P W, P L$ はともに $1.69 \mathrm{~m}$ 拡大 される。

第 2 のグループ (列柱短縮型) の設計手順

セリヌス $D$ 神殿の例, 柱数 $6 \times 13$

$$
\begin{aligned}
& a \times b=6 \times 13 \longrightarrow O W \times O L=18 \times 39 \\
& X \text { を } 3 \text { 単位とする } \\
& \longrightarrow W \times L=16 \times 37 \longrightarrow \rightarrow P X P L=\underset{(5 \times 12)}{15 \times 36,} \\
& \text { 両項 } 1 \text { 娍算両項 } 1 \text { 減算 } \\
& X=4.57885 \mathrm{~m}
\end{aligned}
$$

これらはすべて実測値に対応して修正される。 $O W$ ， $O L$ はともに $3.9 \mathrm{~cm}$ 拡大, $W, L$ はともに $7.8 \mathrm{~cm}$ 縮小, $P W, P L$ はともに $1 \mathrm{~m} 05 \mathrm{~cm}$ 縮小される。このグルー プは 3 単位の他 2,5 単位が用いられる。

第 3 グループ (等間隔柱間型) の設計手順 パルテノン神殿の例, 柱数 $8 \times 17$

$$
a \times b=8 \times 17 \longrightarrow \underset{\uparrow}{\longrightarrow} O W \times O L=24 \times 51
$$

$X$ を 3 単位とする

$$
\begin{aligned}
& \underset{\uparrow}{\uparrow} W \times L=22 \times 49 \underset{\uparrow}{\longrightarrow} P W \times P L=21 \times 48 \\
& \text { 両項 } 2 \text { 減算 } \\
& X=4.2916 \mathrm{~m}
\end{aligned}
$$

これらはすべて実測値に対応して修正される。 $P W$, $P L$ はともに $64 \mathrm{~cm}$ 拡大, $W, L$ はともに $60 \mathrm{~cm}$ 縮小, $P W, P L$ はともに $1 \mathrm{~m} 20.5 \mathrm{~cm}$ 縮小される。このグルー プは 3 単位の他, 2,4 単位が用いられる。

トビンの平面数による平面の設計手順は，数学的技巧 の美しさとは裏腹に実測值との対応による修正を施さざ るを得ない。トビン自身も認めるように円柱の位置は試 行錯誤によらねばならないのである注511。

(3) 堀内の平面グリッド

堀内はクールトンとトビンから出発している。W, $L$ の実測値から柱間や柱間の再配分に関する厳密な公式を つくる。その公式は次の通りである。

Rule $1 \quad I=\frac{L-W}{C_{L}-C_{w}}$

Rule $2 \quad K_{2}=\frac{2\left(N_{L} \cdot W-N_{W} \cdot L\right)}{L-W}$

Rule $3 \quad K_{3}=\frac{2\left(C_{L}-3\right) \cdot W-\left(2 C_{W}-3\right) \cdot L}{2(L-W)}$
ここで, $K_{2}, K_{3}$ は Rule 2, Rule 3 の常数であるがクー ルトン第 3 公式の $k I$ のを $K_{2}$ と $K_{3}$ に細分したもの

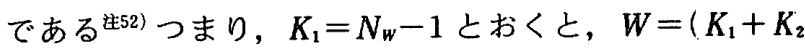
$\left.+K_{3}\right) I$ にって基壇幅（及び奥行）を求めようとした ものである。 $K=K_{1}+K_{2}+K_{3}$ として $W=K \cdot I$ とおく。 設計手順の上で $K \rightarrow K_{1}+K_{2}+K_{3}$ の順序と考えるのが 自然であるから， $K$ とIが先に決定され，それに伴っ てWが後で決定されたことになる。しかし，この方法 で基壇比が成立するのであろうか。基壇に比例を与える ためには基壇が予め決定され，それを柱数で割って柱間 を決定する順序を踏まねばならないであろう。この矛盾 のためにクールトンは柱間 $(I)$ を想定し， $W=K \cdot(I)$ を考えた。トビンは $(I)$ を数值的計算のために $X$ とし， $\left(K_{1}+K_{2}+K_{3}\right) X \rightarrow\left(K_{1}+K_{2}\right) X \rightarrow\left(K_{1}\right) X$ というような 手順を構想し，これが $W, P W$ などの規模決学として 対応させた。

堀内は（I）やX を実在性のないものとして否定し， 単位として実在している古代尺に注目し, 基壇对法や柱 間寸法が古代尺としてビれだけの大きさで施工されてい るかを重視した。古代尺による寸法計画を通して当時の 設計技法を推定しようというのである。しかし，基壇寸 法と柱間寸法の順序問題は棚上げされた。

堀内による古代尺の換算注53) の過程で重要なことは, 指尺, 掌尺, 尺の各段階で端数尺をどう丸めるかであり， その過程で, クールトンの平面グリッドの単位が端数尺 であることに疑問が生じたことである。そして，最初に 設定されるグリッド単位は完数尺と考え，パルテノン神 殿では 1 単位（これを $M$ と略記） 15 尺で, $7 M \times 15 M$ の平面グリッドより設計がスタートとしたと説いた断。 この完数尺単位はクールトン,トビンらの, 柱間単位へ の固執を打ち破っている。また，この単位は，神室と周 柱の設計順序について，神室の設計を先とする考えを表 明している。このことについては次項で論ずる。

堀内の設計手順は,

（1）最初に完数尺単位の平面グリッドを設定する。

（2）柱間，基壇寸法などは上記グリッドと古代尺の 加減乗除（端数をまるめることを含む）によって決定す る，という2段階で構成されている祙5)。

堀内において，柱間単位の平面グリッドが完数尺単位 の平面グリッドに置き換えられただけで，柱間寸法，基 壇寸法の決定順序が設計法の問題として考察されていな い。また，(2) の段階は試行錯誤的で，その方法は次の ような問題点をもっている。

1) 比例との関係が不明である。

2）古代尺の加诚乗除は設計者しかわからない。

3）古代尺の施工寸法の指示は, 膨大な量にのぼり, 混乱や間違いを起こしやすい。

4）部材寸法表をつくっておけばこのような混乱は防 
止できるが,そのような資料は今のところ存在しない。 以上の問題を回避又は軽減するためには,ヴィトル ヴィウスの言うモデュール（モデュラー）・システムを 採用されていたと考えなければならないであろう主56)。 モデュール・システムを施工の作業法としてみた場合, 作業の各段階毎に, 柱間寸法, 柱径などを現寸大で製作 しておき，それに対して，何分の 1 で製作という指示を 与える。施工者は，それをもとに現寸製作定規をつくる。 例えば，後述の計算式で，エンタブラチュア（成）製作 用の現寸定規をつくり，それを $9: 9: 4$ に分割してア一 キトレイヴ，フリーズ，コーニス（成）を製作したと推 定される。

(4) 本研究のグリッド法：グリッド・シンメトリー 本研究のグリッド法は円形より出発する。古代ギリシ

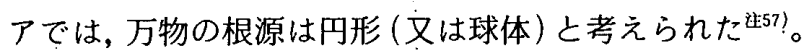
従って建築の形態も, 力学的法則も円形をもとに考えて いたであろう。そして, 力学的法則にもとづく形態の作 図法として, 円形に外接, 内接する $2 つ$ 正方形（これ を双正方形という注58) を利用したと推定する。更に， ギリシア人はこの双正方形を $7 \times 7$ のグリッド図形に還 元して用いたであろう(図一1参照) ${ }^{* 599}$ 。このグリッド 図形は単位寸法のない点集合と考えれば平面数であり， 単位寸法を導入すればモデュール・システムとなる社60)

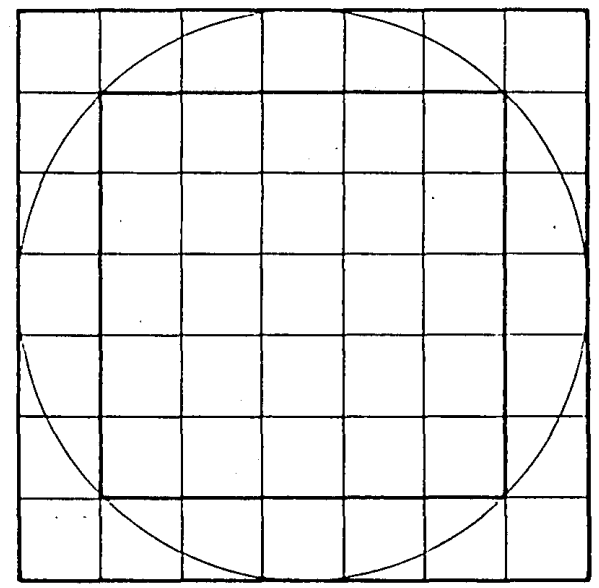

图一1.グリット・シンメトリーの基本図形：双正方形と $7 \times 7$ ギリシア神殿では柱数が先に決定された。この柱数決 定法は上記グリッドを用いて次のように決定されたであ ろう。6×13 柱の場合を考えてみよう。双正方形のグリッ ド図形で, 内接正方形は $5 \times 5$ グリッドである。外接正 方形の $7 \times 7$ グリッドと組み合わせて, 幅 $5 \times$ 奥行 6 単 位のグリッドの平面比ができる。これが, ギリシア神殿 の影響を受けたエトルリア神殿である。これより推測し て奥行 6 単位の 2 倍の 12 単位, すなわち $5 \times 12$ グリッ ドが $6 \times 13$ の柱数決定法であろう。この場合, 円柱はグ リッド交点に建てられる注61)。次にパルテノン神殿の 8 $\times 17$ 柱の決定法を考えてみよう。上記の幅と奥行の構 成に対応して幅 $7 \times$ 奥行 8 のグリッドをつくり ${ }^{\text {\&62 }}$, 奥 行 8 単位を 2 倍して 16 単位とする。かくしてできだ
×16 グリッドが, $8 \times 17$ の柱数を決定する。ここではグ リッドの単位の大きさは問題にしない。

基壇比は柱数比（正面柱数と側面柱数の比）に連動す る。 $W: L=C_{w}:\left(C_{L}+1\right)$ というクールトンの平面公 式において, 奥行の柱数単位が 1 単位増加していること に注目する。このことは基壇規模と，周柱軸線の長方形 がおおむ敉合致することを考えると， $C_{W} \times\left(C_{L}+1\right)$ と して初めに構成された基壇が，W×Lの基壇（実施さ れた規模）に比例縮小（比例を維持しながら縮小するこ と，縮小相似形をつくること）されたことを推定させる。 このことは基壇 $W, L$ の実測値を等分割してもグリッ ド単位はでてこないことを示す。トビンの分類する第 3 グループのみが柱間にグリッド単位を保持している。パ ルテノン（第 3 グループ）の基壇規模は 8 対 18 (4 対 9) の比になっているので, これを柱数決定の $7 \times 16$ のグ リッドとの関係でみると, 幅において 1 単位, 奥行にお いて 2 単位増加している。つまり，この分量だけ基壇規 模に比例縮小がかかっている（厳密には幅において 0.8 単位, 奥行きにおいて 1.8 単位縮小)。ここで, 4 対 9 は, $9=4 \times 2+1$ であることに注目する必要がある。W $: L$ $=C_{w}: C_{L}$ という関係が幾何学的に実現不可能な状況下 で, $L=W \times 2+1 （ W, L$ を 4 と 9 の単位数とする）の 関係式と, $C_{L}=C_{w} \times 2+1$ という関係式の形の一致とい うことを実現している社631。つまり, 比の一致が関係式 の一致に置換されたのである。しかも, 4 対 9 は, $1: \sqrt{5}$, （2つの正方形の辺長と対角線の比）の整数近似解とい う絶妙の比を示している。

次に, 基壇寸法と柱間寸法の先決問題である。この点 で，パルテノンにおいて堀内の発見した平面グリッドが 画期的意義をもっている。前述の堀内の公式は

$$
W=K_{1} I+K_{2} I+K_{3} I=\left(K_{1}+K_{2}+K_{3}\right) I
$$

$K_{1}=$ 柱間数 $N_{w}-1 ; K_{2}=\frac{1}{2}, K_{3}=1$ のときRule 1; $K_{2} \neq \frac{1}{2}, \quad K_{3}=1$ のとき Rule $2 ; K_{2}=\frac{1}{2}, K_{3} \neq \frac{1}{2}$ のとき Rule $3 ; K_{2} \neq \frac{1}{2}, K_{3} \neq 1$ のとき Rule 4 である。

先に, $W=K I$

とおいた。同時,この公式は矛盾をもっていることを指 摘した。そこで, クールトンの $(I)$ の代りに堀内の $M$ を置いて前述のクールトンの設計手順を書き換えると,

柱数 $C_{w} \longrightarrow$ 基壇規模 $(W) \longrightarrow$ 䒠際の柱間 $I$
完数尺単位 $M \quad$ 柱数 $C_{W}$ で分割

（注）神殿正面だけに注目する。(W)の（）は修正前を示す。 となる。この図式で問題が起こらないだけでなく, 決定 法が秩序立ったものになる。これをグリッドとの関係で 図式化すると，次のようになる。

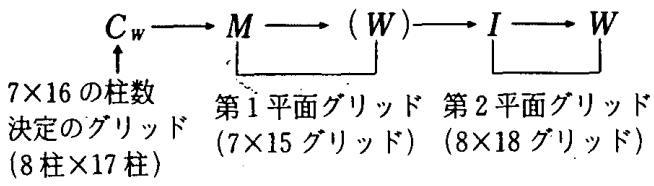


ここで, 柱数決定のグリッドの単位は第 2 平面グリッ ドと一致させる。基壇幅 $W$ は $(W) \rightarrow W$ として決定 されたことを示す。ここでも第 1 平面グリッドは $15=7$ $\times 2+1$ の関係式となっていることが注目されよう。

以上の図式の正当性を実測值で検討してみよう。

第 1 平面グリッドで $(W)=7 \times M=7 \times 15=105$ 尺, $(W) \div C_{W}=105 \div 8=13 \frac{1}{8}=$ 柱間 $I$ (実測值に一致) で ある。この柱間単位をもとに 8 対 18 の第 2 の平面グリッ ドを組む。このグリッド内で $W, L$ を決定する。

以上から(2)の式は $(W)=K^{\prime} M, K^{\prime}$ は単位数を示す整 数, と書き直すことができる。これが第 1 平面グリッド の正面幅の公式である。次に, $(W)=C_{w} I$ で, この式 より $I$ を求め, $I$ による平面グリッドがつくられる。最 後に, $W=\left(K_{1}+K_{2}+K_{3}\right) I$ で, 隅柱間の位置, 基壇の 大きさを決定するき64)。

万物の根源は球体であるとすれば，平面に使用した円 形は，立面にもそのまま適用できる。そこで，パルテノ ンの平面グリッドをそのまま立面にも適用する。立面で は, $7 M \times 3 M$ (第 1 立面グリッド) を出発点として, 柱間 $I$ のグリッドを併用する。ここでも $7=3 \times 2+1$ の 関係式となっていることに注目される。柱間 $I=13 \frac{1}{8}$ 尺であるから柱高 $=3 M$-柱間 $=45-13 \frac{1}{8}=31 \frac{7}{8}$ 尺（実 測值に一致）となる。更に、ペディメント成が柱間 $I$ となっているので, 柱間 $I$ の第 2 の立面グリッドは $8 I$ $\times 5 I$ とし, 高さ $3 M$ と $4 I$ の水平線を一致させる。地

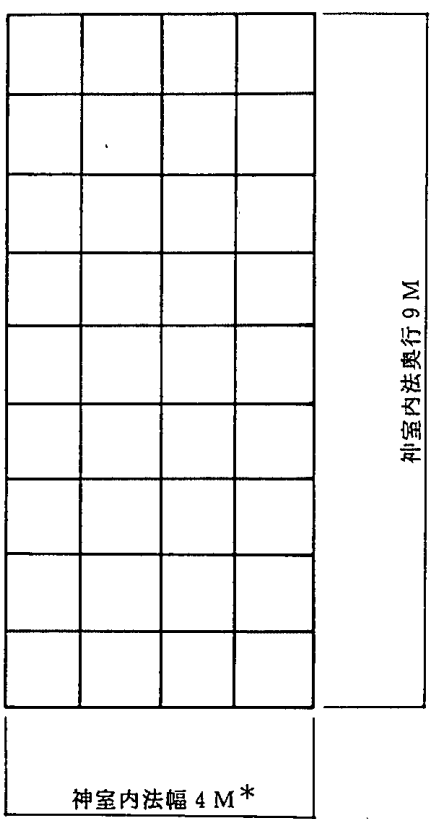

図一2 神室内法のための平面グリッドの 設定 $4 M \times 9 M, 1 M=15$ 尺, 4 対 9 の比例の源泉*印は修正され る寸法値, 以下, 略号, 印の意味 は同様

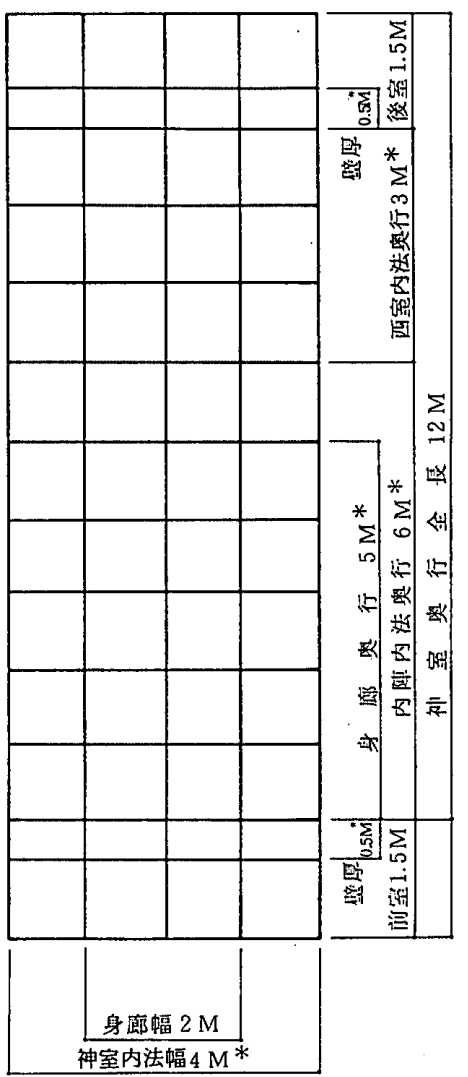

図一3 神室内法の平面グリッドによる 平面設計 (堀内による)
盤から基盤面までの高さを大体に於いて 10.5 尺（3.44 $\mathrm{m}, 4 I-42$ 尺）の高さ蛙5) として考えると，8 対 5 は黄 金比の近似整数比であることは注目すべきことである。 正面比 (基壇偪と, 基壇上面からコーニス上端までの比) には基壇比の 4 対 9 を適用して修正される。以上の詳論 は次章で行なう。

以上, グリッド法の適用においてパルテノンの形態が 決定されたとすれば，(3）節の冒頭で述べた第 3 の美的 形態をつくりだす条件をもグリッド法は満足しているこ とになる。簡単・正確につくることなどの施工条件を技 術, 美しい形態をつくることを芸術と考えると，グリッ ド法は技術と芸術を統一した方法である。古代の設計法 はシュムメトリアと称されることは前述したが，本研究 のグリッド法は，グリッド的シュムメトリアまたは，グ リッド・シンメトリーと総称できよう。

2. グリッド法にもとつくパルテノン神殿の設計手順

グリッドの共約 (シンメトリー, 幾何学図形に対応し た整数比例で構成された）的図形を繰り返し使いながら パルテノン神殿の各部寸法を決定してゆく。この設計手 順は大きく 3 つに分けることができる。

第 1 は，神室（セラ又はセコス）の平面設計で，その 内法規模, 身鿾規模, 境壁による内陣（ナオス, 主室之: も邦訳される) と西室（パルテノンと呼ばれた後部の部 屋) の間仕切り, 前室 (プロナオス), 後室 (オピスト ドモス）の規模などがこれに含まれる。

第 2 は, 神殿の平面設計 (単に平面 設計と略す) で, 周柱（柱の位置, 柱 径, 柱間, 隅柱間の短縮）の胁定と基 壇嫢模, 階段 (クレピス) の幅の決定 がこれに含まれる。

第 3 は, 神殿の立面 (正面) の設計 で, 柱高, 柱頭成, エンタブジュデ 高（基壇からコーニス上端まで，オ一 ダー総高とも言う), エンタブラチュ ア成, ペディメント成などがこれに含 まれる。

本章において実測値は前記の主要才 法の推定值のことである。神宣前後の 壁厚など一部不足している寸法值はペ ンローズの実測值に基づき尺寸に換算 した。その時はその都度明記した。堀 内の論考注66)を参照した時は, 堀内に よると明記した。その他必要と思われ る事項は注記した。

（1）神室の平面の設計手順

第 1 手順 : 神室内法平面グリッドの 設定, 図一 2 参照。

$1 M=15$ 尺, 幅 $4 M^{*}$, 奥行 $9 M$ の 


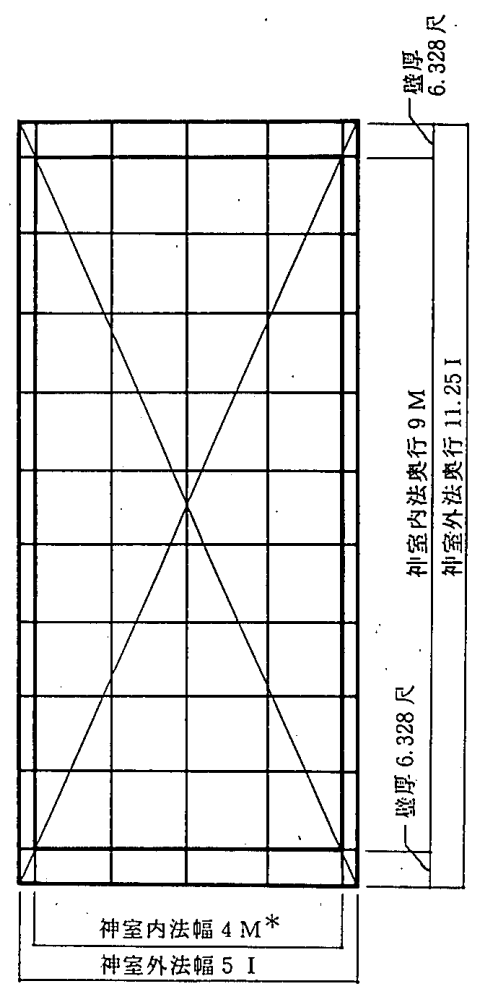

図一4 神室外法平面の決定 4 対 9 の比例を利用

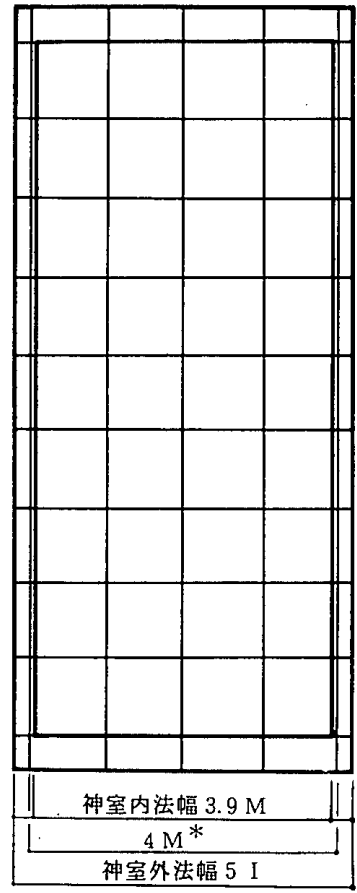

図一5 側壁厚の決定

神室内法幅を $\frac{1}{10} M$ 縮小

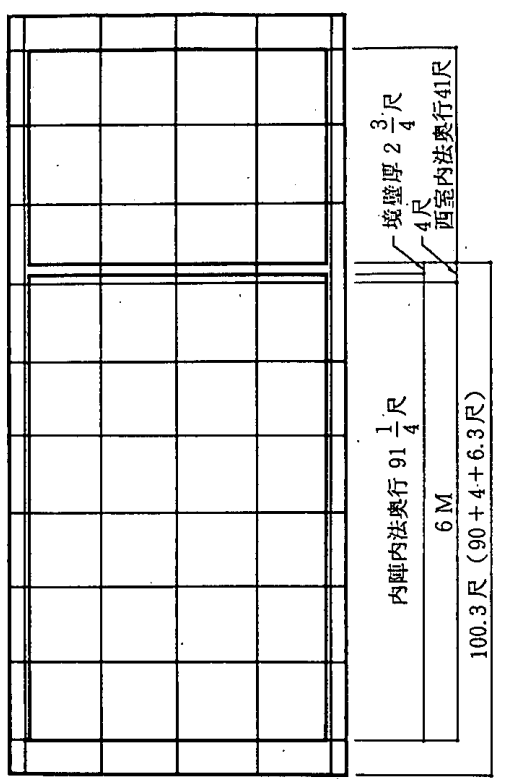

図一6境壁の位置と厚さの決定その 1 (堀内の説を図化)
平面グリッドを設定する。これが神室平面内法を決定す る。ここで*印は後で修正される寸法を意味する。 $4 \times 9$ の平面グリッドの比は, その後の 4 対 9 の比例の源泉で ある。

第 2 手順：神室内法平面グリッドによる間仕り 図一 3 参照。

$4 M \times 9 M$ の平面を, 奥行き方向に $2: 1$ に分け, 前 部のものを内陣(ナオス), 後部のものを西室とする。従っ て, 内陣奥行きは $6 M^{*}$, 西室奥行きは $3 M^{*}$ である。 内陣には，身廊（列柱に囲まれた部分）を設け，スタイ ロベート内法間で幅 $2 M$ ，奥行きを $5 M^{*}$ とする。 $4 M$. $\times 9 M$ の平面グリッド前後には $1.5 M$ の奥行きの前室 (プロナオス), 後室 (オピストドモス) をとりつけ, 内陣，西室との壁厚を $0.5 M^{*}$ とする。以上，図・説明 (筆者構成)ともに堀内による。

第 3 手順：神室外法平面の決定, 図一 4 参照。

第 3 6 手順は柱間単位の平面グリッドの決定後に行 なわれるものであるが，ここでまとめて説明する。

4 対 9 の矩形を比例拡大 (比例を維持しながら拡大す ること，拡大相似形をつくること）し，外法幅を 5 柱間 (5I と略記), 外法奥行をその $\frac{9}{4}$ に相当する $11.25 I$ の大きさとする。外法幅 $5 I$ は実測値 $65 \frac{5}{8}$ 尺に一致す る。側面壁厚は 2.8125 尺*となるが, 次の手順で搪張 される。

前後出入口の壁厚は, 6.328 尺で, ペンローズによる
実測值は 6.29 尺（6.760 ft のドーリア尺換算）に 0.038 尺 $(1 \mathrm{~cm} 2 \mathrm{~mm})$ の誤差で一致する。外法奥行 $11.25 I$ $=147.656$ 尺（図で, $147 \frac{2}{3}$ 尺と記す).は, ペンローズ の実測値 147.413 尺（前後の出入口の壁厚 $6.76 \times 2+$ 内 陣内法奥行 $98.080+$ 境壁厚 $3.025+$ 西室内法奥行 $43.767=158.3925 \mathrm{ft}$ のドーリア尺換算）に 0.243 尺（約 $8 \mathrm{~cm})$ の誤差で一致する。ちなみに, 外法奥行を $5 I \times$ $\sqrt{5}=11.18 I=146.7375$ 尺で, 147.413 尺に 0.6755 尺 $(22 \mathrm{~cm})$ の誤差である。

第 4 手順：側壁厚の決定, 図一5参照

神室内法幅を $\frac{1}{10} M$ だけ縮小。その結果, 内法幅は $3.9 M=58 \frac{1}{2}$ 尺で, ペンローズ実測值 58.64 尺(63.01 ft のドーリア尺換算）に0.14尺 $(4 \mathrm{~cm} 6 \mathrm{~mm})$ で一致 する。側壁厚は 3.56 尺 $(2.81+0.75)$ はペンローズ実 測値 3.56 尺（3.83ft のドーリア尺換算）に一致する。 ちなみに，堀内は側壁厚を 3.5 尺に修正，その結果内法 幅は $58 \frac{5}{8}$ 尺になったとする。

第 5 手順：境壁の位置と厚さの決定, その 1

$$
\text { 図一 } 6 \text { 参照 }
$$

同上：同上 その 2 図一7 参照

内陣と西室を仕切る境壁は, 概略的に述べると柱間数 を 5 対 $3(10$ 対 6) に分ける円柱の位置に対応している。 その正確な位置と境壁厚の決定法は今後の検討の余地も あるが，1つは堀内説を図化（図一6）, もう1つはワト キス・ロイドの比例説を前述のグリッドに適用して図化 


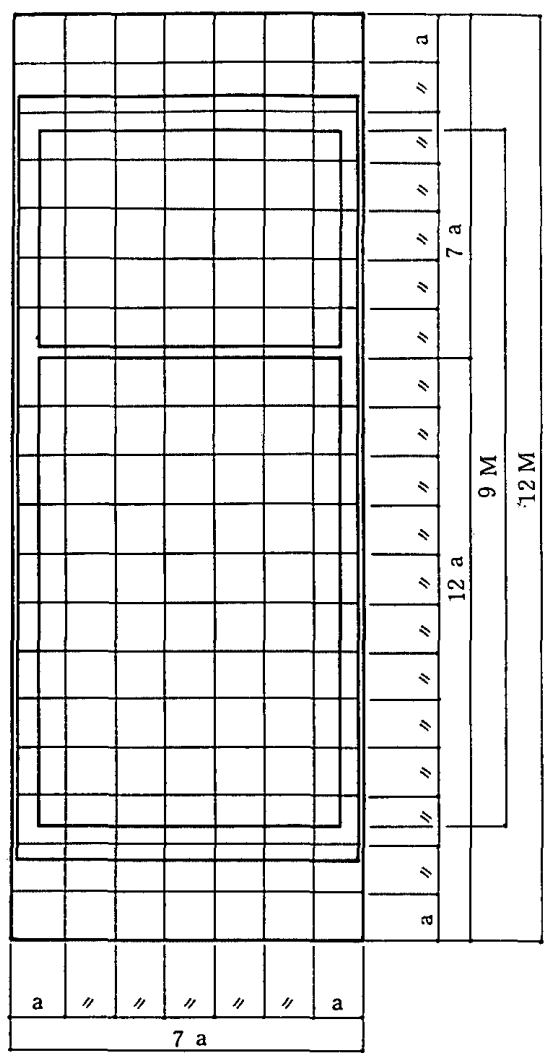

图一7境壁の位置と厚さの決定その 2

(ワトキス・ロイドの比例説を適用・図化) $a=\frac{12}{19} M \doteqdot 9.47$ 尺

（図一7）したものを紹介する。

堀内説（図一6参照）を解説すると次の通りである。

内陣奥行をを西室側に 94 尺に拡大する。境壁厚を $2 \frac{3}{4}$ 尺とし，94 尺の内側にとる。その結果，内陣内法奥行 は $91 \frac{1}{4}$ 尺となる。西室内法奥行は 41 尺となる（堀内の 論考 p. 8)。内陣総奥行（出入口, 境壁厚を含めた奥行) は 100.3 尺（94+6.3）である。

ワトキス・ロイドの比例説（図一7参照）は，神室基 壇（通常の基壇とは異なる）の幅と西室奥行（後室玄関， 出入口壁厚, 境壁を含む) とが同一寸法（1 対 1) であ ることに注目し，この寸法を 79 とおくと内陣奥行（前 室玄関, 出入口壁厚, 内陣奥行の和）は $12 a$ になると 言う告67)。これを $4 M \times 12 M$ グリッドに適用して図化し たのが図一7である。 $\frac{12 M}{19}=9.47$ 尺 (=1 $a$ とおく ), 内陣奥行 $12 a=113.68$ 尺で, 図一7 の計算値 113.75 尺 に 0.07 尺 $(2 \mathrm{~cm})$ の誤差で一致する。また, 西室奥行 $7 a=66.32$ 尺は，図一7 の計算値 66.25 尺に同じく 0.07 尺 $(2 \mathrm{~cm})$ の誤差で一致する。なお，神室基壇の 幅と長さはペンローズの実測値でそれぞれ，66.386尺 (71. $330 \mathrm{ft}$ のドーリア尺換算)，180.305尺（193.733ft のドーリア尺換算）である。

第 6 手順：身廊の奥行の決定，図一8参照

身廊奥行を 3 尺後退して 48 尺とした。身廊列柱スタイ

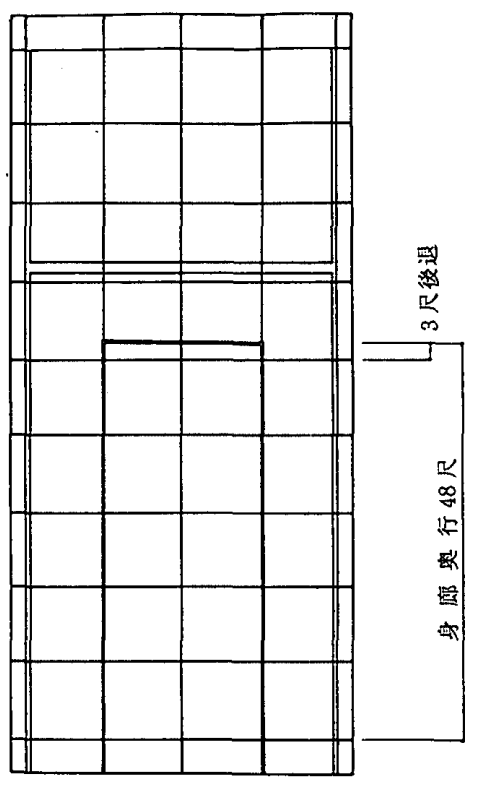

图一8 身廊の奥行の決定（堀内の説を図化）

ロベート幅は $\frac{1}{4} M=3 \frac{3}{4}$ 尺とした。以上堀内による(p.8)。

(2) 平面の設計手順

第 1 手順： $7 M \times 15 M$ の平面グリッドの設定 図一 9 参照

この平面グリッドは堀内による。堀内は，神室内法を 定めている平面グリッドを拡張して， $7 M \times 15 M, 1 M$ $=15$ 尺のグリッドがパルテノン神殿平面の出発点であ ると説いた。既往の研究では柱間単位の平面グリッドが 出発点之考えられた。設計の出発点の単位は完数尺であ ることが自然で，もし，柱間を完数尺と考えると，同じ ギリシアの中で，場所によって建物によって 1 尺の長さ がばらばらとなる問題が生じる。そこで, 堀内は, 柱間 単位は完数尺ではなく, 端数のついた非完数尺としなけ ればならないとし，そのために，柱間を設計の出発点と するグリッドを放棄した。ここで，改めて完数尺単位の 平面グリッドを出発点に置いたのである。

$7 M \times 15 M$ は， $O W \times O L$ の大きさに完全に一致しな いが，概略的大きさにおいて一致している。この大きさは $15=7 \times 2+1$ という関係式になっている点が注目される。

第 2 手順：柱間単位の $8 I \times 18 I$ の平面グリッドの生成 図-10参照

堀内の新説は, 柱間単位の平面グリッドの欠点（非完 数尺）を克服したが，その設計上の利点も失なった。そ のため, 完数尺単位の平面グリッドから柱間単位の平面 グリッドを派生させることができれば，柱間寸法の非完 数尺問題も解決され，設計上の利点も生かすことができ る。今, 正面 $7 M=105$ 尺を 8 等分すると柱間 $I=\frac{105}{8}$ $=13 \frac{1}{8}$ 尺で実測値に一致する。このことは $M$ グリッド

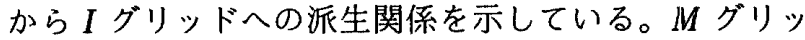
ドを $I$ 単位で改めて組み直したのである。側面は 4 対 9 の比で $18 I$ とする。ここで $15 M=225$ 尺, $18 I=$ 


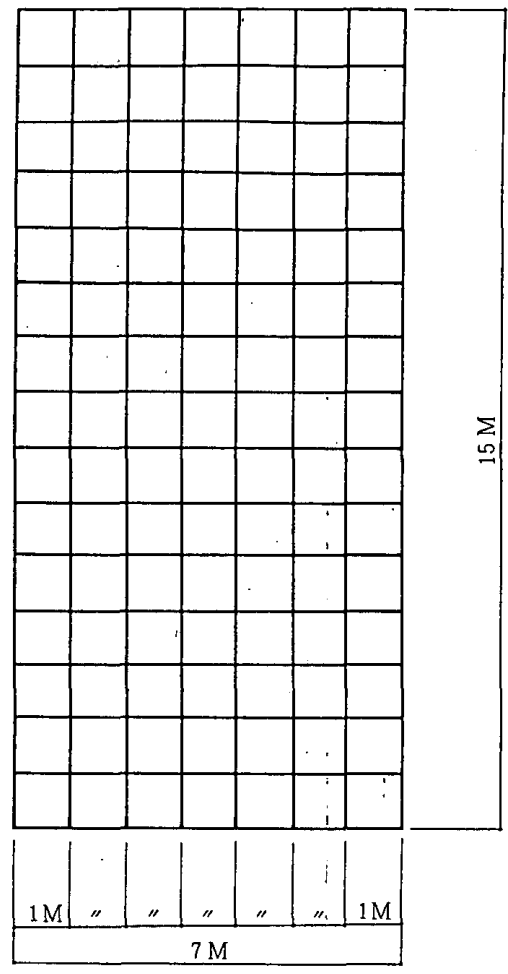

図一9 $7 M \times 15 M$ の平面グリッドの設定（堀内による）

最初に設定される平面グリッドは神室平面グリッド （図一2）の拡張であること, ングリッド単位が完数尺で あることなど設計法研究に画期的意義をもっている。こ こで平面とは神殿全体の平面のことである。

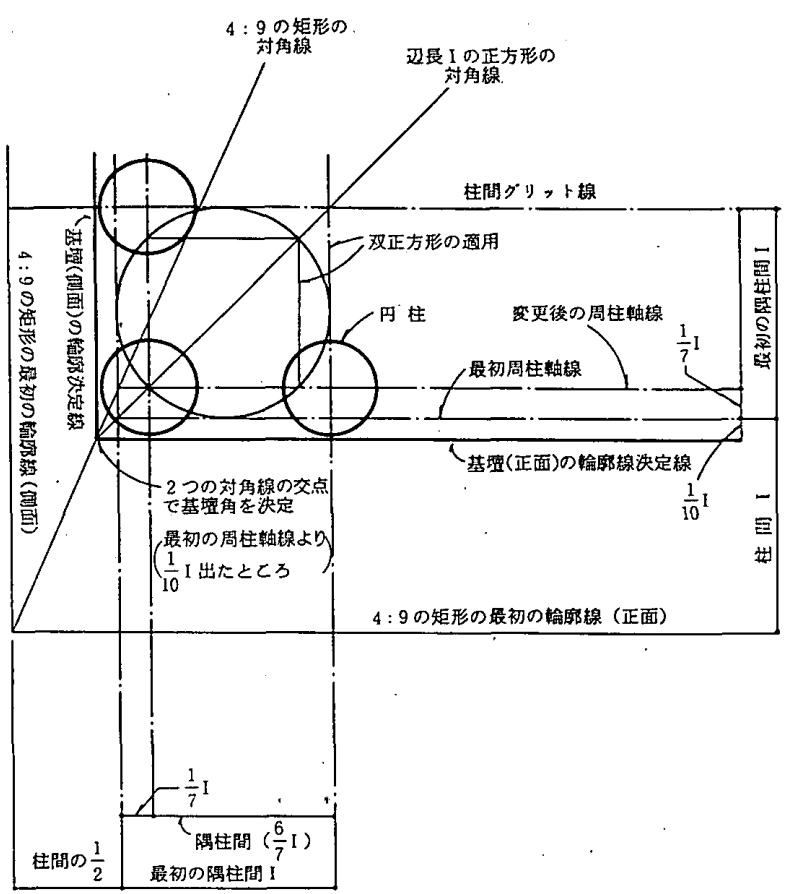

図一11隅柱間の短縮と基壇規模の決定

図一10の点描部分に双正方形を適用して踝柱間を短 縮する。基壇の大きさは，4 対 9 の矩形（柱間単位の 平面グリッド) の対角線と, 点描部分の正方形の対角 線の交点により 4 つ角を決定する。

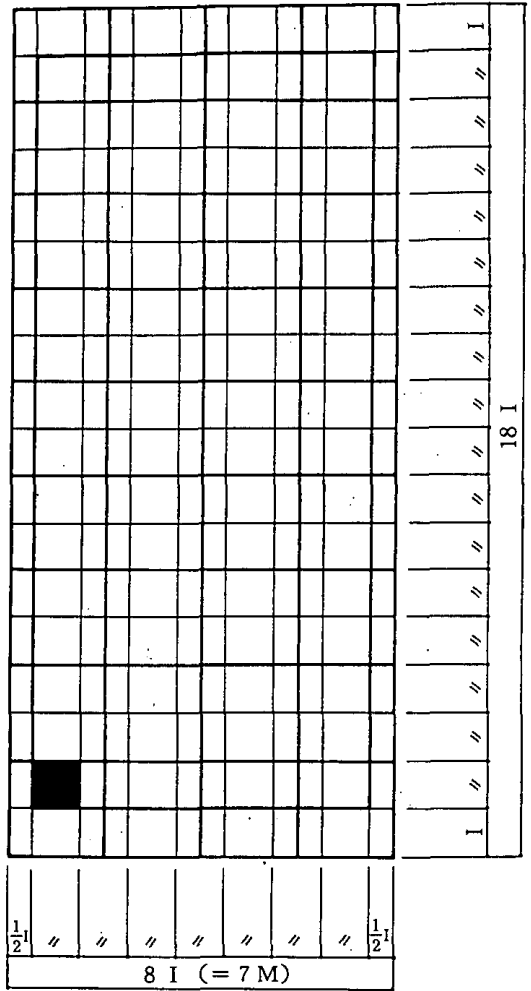

図一10 柱間単位の平面グリッドの生成

正面幅 $7 M$ を 8 等分して柱間 ( $I$ と略記) を割り出 し, 正面 $8 I$ に対して，4 対 9 の比例を適用して奥行を $18 I$ とするグリッドをつくる。図中の太線は 4 対 9 の 比例と周柱軸線（修正前）を表示。寸法線と対応して いる太線と細線が柱間単位のグリッド線。点描部分は 図一11 参照

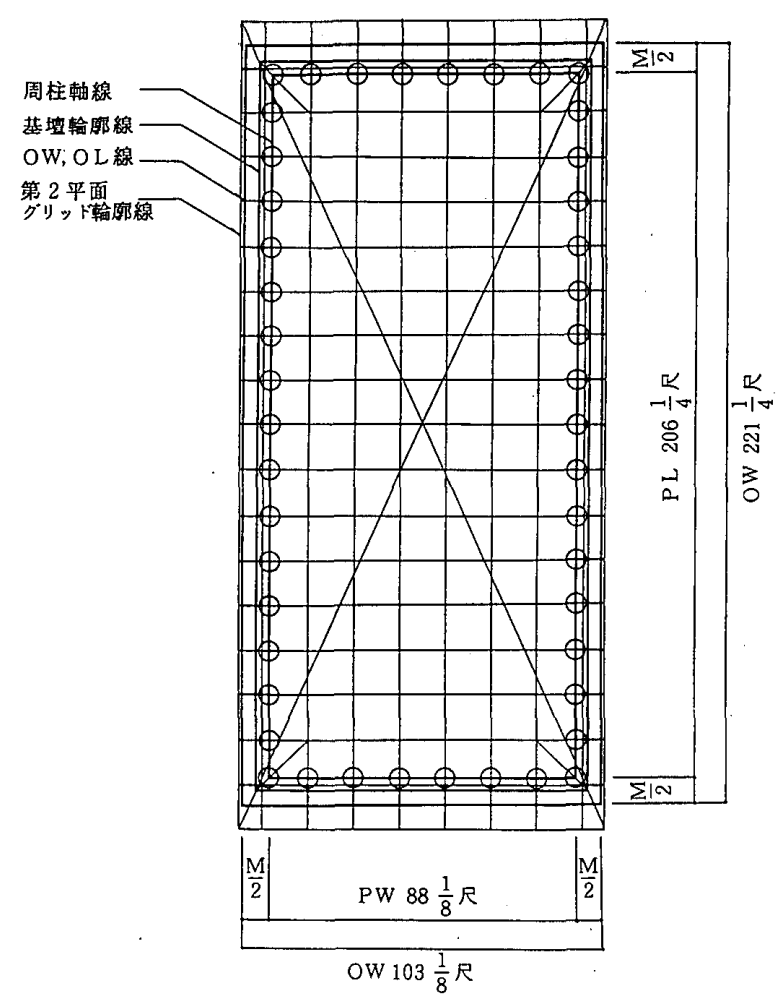

図一12 OW, OL の決定 $O W=P W+M, O L=P L+M$ により決定 
236. 26 尺で側面の長さは一致しない。グリッドの派生 には正面幅を重視していることがわかる。派生関係は， 105 尺 $=15$ 尺 $\times 7$, $\frac{105}{\text { 柱数 } C_{w}}=\frac{105}{8}=13 \frac{1}{8}=$ 柱間 $I$ であ る。ここで 4 対 9 は, $9=4 \times 2+1$ の関係式でできてい ることが注目される。

本研究の柱間単位グリッドは, 実際の柱数と直接関係 しない。クールトンは, 柱数に応じて, 例えば $8 \times 17$ の 平面グリッドをつくる。本研究は, 基壇比 4 対 9 に対応 する $8 \times 18$ の平面グリッドをつくり，この平面グリッド が比例縮小されて柱数 $8 \times 17$ になると考える。これが柱 間単位の平面グリッドにおける本研究とクールトンとの 違いである。

第 3 手順：隅柱間の短縮と基壇規模の決定 図-11 参照

筆者は, 古代ローマ・パンテオンの設計法の考察で, 双正方形（双正方形双円形接合図形）の幾何学図形が利 用されていることを推定した ${ }^{\text {世68) }}$ この双正方形をパルテ ノン神殿の隅柱間の短縮法とし利用した。双正方形は 7 $\times 7$ グリッドに置きかえられ，その 1 単位 $\left(\frac{1}{7} I\right)$ が短 縮されたと考える。短縮量 $=\frac{1}{7} I=1 \frac{7}{8}$ 尺で実測值に一 致する。また，隅柱間は $\frac{6}{7} I=11 \frac{1}{4}$ 尺で実測值に一致す る。その結果, $P W=5 I+\frac{6}{7} I \times 2=88 \frac{1}{8}$ 尺, $P L=14 I$ $+\frac{6}{7} I \times 2=206 \frac{1}{4}$ 尺でともに実測值に一致する。

次に基壇規模の決定についてである。柱間単位の平面 グリッドの 4 対 9 の比が維持されるように，4 対 9 の矩 形に対角線を描く。基壇の 4 隅がこの対角線上にあれば 4 対 9 の基壇比が成立する。一方, 基壇の端部は, 隅柱 の中心より等距離に位置するために周柱軸線の矩形の 4 隅から 45 度（矩形の辺に対して）の線上に基壇の 4 隅 がなければならない。この 45 度の線は, 図一10に示し た点描部分の正方形の対角線である。両対角線の交点が 基壇の 4 隅である（図一11も参照）。かくして, 縮小前 の周柱軸線矩形に対して周囲 $\frac{1}{10} I$ だけ挔大した大きさ が基壇規模の決定法である。 $W=7 I+\frac{1}{10} I \times 2=\frac{36}{5} I$ $=94 \frac{1}{2}$ 尺, $L=16 I+\frac{1}{10} I \times 2=\frac{81}{5} I=212 \frac{5}{8}$ 尺で, 実 測値に一致する。 $\frac{1}{10} I$ に相当する部分を $x$ として, 計 算で $x$ の大きさを求めてみよう。 $x:\left(x+\frac{1}{7}\right) I=4: 9$ である。 $x=\frac{4}{35} I=0.1143 I \fallingdotseq 0.1 I=\frac{1}{10} I$ となる。クー ルトンは, パルテノンについて $W=I\left(N_{W}+\frac{1}{5}\right)$ として いる。この $\frac{1}{5}$ は, $\frac{1}{10} \times 2$ として得られる。

第 4 手順: $O W, O L$ の決定, 図一12 参照

周柱軸線の矩形の周囲に $\frac{1}{2} M$ の幅を巡らして $O W$, $O L$ とする。従って, $O W=P W+1 M=88 \frac{1}{8}+15=103$ $\frac{1}{8}$ 尺, $O L=P L+1 M=206 \frac{1}{4}+15=221 \frac{1}{4}$ 尺で実測值に 一致する。以上, $O W, O L$ の計算式は堀内による (p.5)。

(3) 立面の設計手順

第 1 手順 : $7 M \times 3 M$ の立面グリッドの設定 図-13 参照
$1 M=15$ 尺の単位のグリッドを出発点とすることは 平面の場合と同じである。このグリッドは $7=3 \times 2+1$ の関係式をもっており，第 1 ，第 2 平面グリッドにみら れた関係式の形と同じである。

第 2 手順：柱高とペディメント成の決定

$$
\text { 図-14 参照。 }
$$

前述の立面グリッドの $3 M$ の高さの水平線の上・下 に柱間 $I$ の幅の水平線を描く。立面の柱割りは, 左右

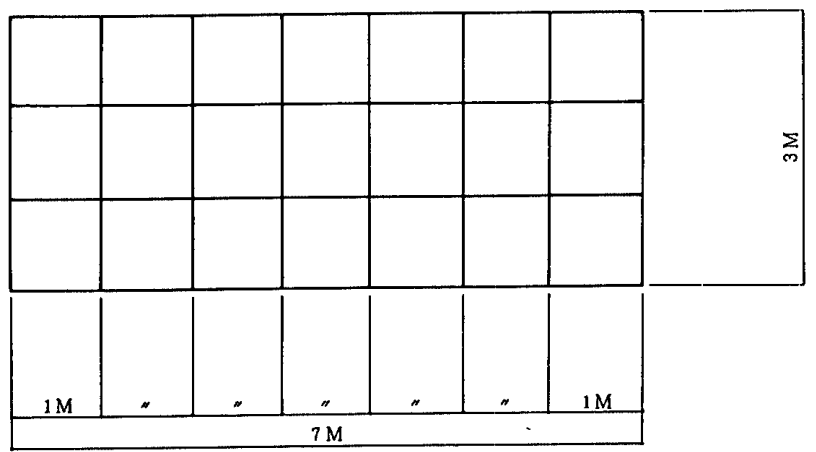

図一13 立面設計のために幅 $7 M \times$ 高さ $3 M$ の立面グリッドの設定

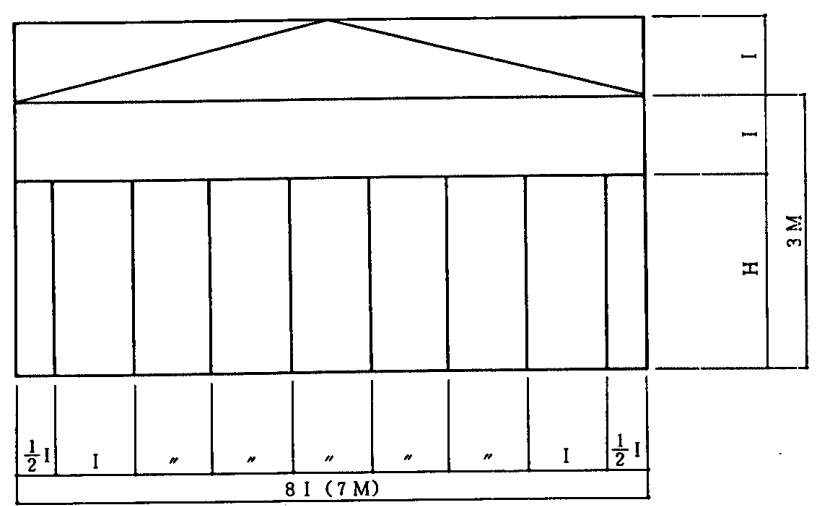

图一14 柱高 $H$ とペディメント成の決定 $3 M$ の高さの水平線の上・下に柱間 $I$ の幅 の水平線を描く。

柱高 $H=3 M-I=31 \frac{7}{8}$ 尺, ペディメント成 $=I$

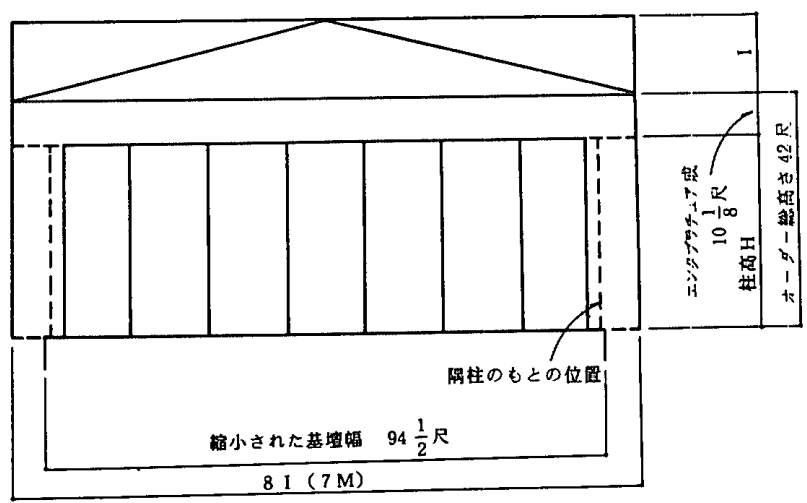

図一15 エンタブラチュア成の決定

基增幅 9 に対してオーダ一総高さを 4 とする。 エンタブラチュア成＝オーダー総高さ一柱高= 42 尺 $-31 \frac{7}{8}=10 \frac{1}{8}$ 尺 
に $\frac{1}{2} I$ をとった形で 8 等分する (図一10 も参照)。

ペディメント成は柱間 $I$ とする注69)。ペディメントの 成を傾斜角でみると, $\tan \theta=\frac{1}{4}, \theta=14^{\circ}$ で, $13.5^{\circ}$ の実 測値蜭11)に一致している。柱高. $H$ は, $H=3 M-I=45$ $-13 \frac{1}{8}=31 \frac{7}{8}$ 尺で実測值に一致する。基壇の高さ $h$ は, $h=2.5 M-H=37.5-31 \frac{7}{8}=5.625$ 尺で, ペンローズ

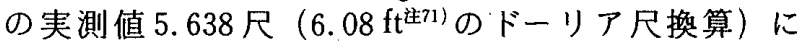
0.013 尺 $(4 \mathrm{~mm})$ の誤差で一致する。 5.625 尺を 50 等 分し, 下方より，7，14，14，15 の比で 4 層の階段の高 さを構成した这72\}。柱径（底部）は 4 対 9 の比を用いて, $\frac{4}{9} I=5 \frac{5}{6}$ 尺(実測值に一致)とした ${ }^{\text {主73)。 }}$

柱高について R.W.ガードナーの説（本文 1-(2) 参 照) を用いると $H=\sqrt{5} I+\frac{1}{5} I=10.47 \mathrm{~m}$ という決定法 が生じる。この值は, 実測値 $10.43 \mathrm{~m} に 4 \mathrm{~cm}$ の誤差で 一致する。本稿の $H=3 M-I$ の決定法（この決定法で は $H=10.4391 \mathrm{~m}$ で $9 \mathrm{~mm}$ の誤差）とどのように両立し うるのであろうか。 $H=3 M-I$ の決定後に, 柱身 $\sqrt{5} I$, 柱頭成 $\frac{1}{5} I$ に割り振ったと考えられる。

柱高決定に関してゼウス神殿（オリンピア，前 470 456 年頃) の柱高との同一性の問題がある。これについ てカーペンターは，旧パルテノンの柱高をまねたとし， 現在の新パルテノンの柱高も旧パルテノンの円柱の高さ をそのまま移して決められたと言う壮74)。パルテノン神 殿の設計手順の中で，柱高が先に決定されたとは到底考 えられない。それで旧パルデンがペルシア軍によって 焼き払われた前 480 479 年後からゼウス神殿着工の前 470 年までの間に新パルテノンの設計図面が完成し，そ の図面から柱高寸法をまねてゼウス神殿ができたと考え なければならない。一方, ゼウス神殿は柱高 2 単位とし て柱間を 1 単位とする簡単なグリッド法が適用されてい るので柱高が先に決定されたとしても問題は起らない情75)。

第 3 手順：エンタブラチュア成の決定, 図一15参照。

平面の第 3 手順で基壇の大きさが決定された。この基 壇幅を 9 として，コーニス上端の高さ（第 1 手順の 3 $M$ の高さ)を 4 の比に縮小する（正面比 4 対 9 の成立）。 その結果, コーニス上端の高さは $94 \frac{1}{2} \times \frac{4}{9}=42$ 尺でエ ンタブラチュア成は，42 尺一柱高 $H=10 \frac{1}{8}$ 尺となり， それぞれ奏測値に一致する。

\section{3. 結 び}

パルテノン神殿は，グリッド法にもとづいて次のよう な設計手順で設計された。既往の研究で示されている項 目，内容については**印を付した。

(1) 神室平面設計のために 1 単位 15 尺(これを $1 M$ と略記）の， $4 M \times 9 M$ のグリッド**を設定した。こ れが完数尺単位の平面グリッドで，周柱よりも神室が優 先的に設計されたことを示す（図一 2 参照）。

(2) 神室をとり巻く周柱や基壇などの神殿平面設計の
ために上記完数尺単位グリッドを拡張し，正面幅 $7 M$ ×奥行 15 の単位数をもったグリッド**を設定した（図 -9 参照)。

(3) 上記 $7 M \times 15 M$ グリッドの正面幅 $7 M$ を 8 等分 し，この 1 単位を柱間 ( $I$ と略記) とする。1柱間 $(1 I)$ は $13 \frac{1}{8}$ 尺となる。正面幅 $8 I$ に対して奥行を $18 I$ の 4 対 9 の比のグリッドをつくる。これが柱間単位の平面グ リッドである（図一10参照）。

(4) 隅柱間は, 双正方形の幾何学図形より生成した 7 ×7 グリッドを利用して, 正面幅方向及び奥行方向とも に 1 単位ずつ減少して, $\frac{6}{7} I$ の大きさに短縮された。そ の結果, 隅柱間は正面・奥行ともに $11 \frac{1}{4}$ 尺となった(図 -11 参照)。

(5) 基壇規模は, 正面・奥行の隅柱間で構成される正 方形の対角線と，上記 4 対 9 の柱間単位の平面グリッド の輪郭矩形の対角線との交点を 4 隅とするように幾何学 的に決定された。この決定法は，短縮前の隅柱中心より 正面幅方向及び奥行方向に $\frac{1}{10} I$ ずつ張り出した矩形を 基壇規模とする決定法に置換できる。これらの決定法に より基壇正面幅は $94 \frac{1}{2}$ 尺，同奥行は $212 \frac{5}{8}$ 尺となった (図-11 参照)。

（6）基壇外回りの階段を含めた正面幅 $O W$ と奥行き $O L$ は，短縮移動された隅柱中心（すなわち周柱軸線） より正面幅方向, 奥行方向ともに $\frac{15}{2}$ 尺 $\left(=\frac{M}{2}\right)$ ずつ張 り出した規模で決定された。その結果， $O W=88 \frac{1}{8}+15$ $=103 \frac{1}{8}$ 尺**，OL=206 $\frac{1}{4}+15=221 \frac{1}{4}$ 尺**，階段幅は 正面・側面ともに $4 \frac{5}{16}$ 尺となった（図一12参照）。

(7) 立面設計の第 1 段階として, 正面幅 $7 M$ に対し て高さ $3 M$ とするグリッドを設定した（図一13参照）。

(8) 立面設計の第 2 段階として，上記グリッドの 3 $M$ の高さの上・下に， 1 柱間単位（1I），の幅をとる。 こうして, 柱高 $H$ は, $H=3 M-I=45-13 \frac{1}{8}=31 \frac{7}{8}$ 尺 として决定された（図一14参照）。ペディメント成は柱 間の大きさで $13 \frac{1}{8}$ 尺**として決定された。柱径（底部 の直径)は，柱間の $\frac{4}{9}$ として $5 \frac{5}{6}$ 尺**に決定された。

(9) 立面設計の第 3 段階として，上記(5)の基壇幅 94 $\frac{1}{2}$ 尺の $\frac{4}{9}$ となるように上記(7)の $3 M$ を縮小する。その 結果, オーダー総高さは 42 尺とった。エンタブラチュ

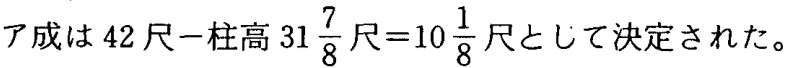

\section{謝 辞}

本稿を作成するにあたり熊本大学の堀内清治，伊藤重 剛両先生より助言を得ました。記して御礼申し上げます。

注

1) 設計手順 design procedure or design process が施工の作 業手順と対応するということは，現場で各部寸法を現寸 大で $1 つ 1 つ$ 順番に决定してゆくことを考虑した設計図 のつくり方という意味である。この方法論的考え方はグ 
リッド法特有のものである。グリッド法については本文 1一(4)参照。

2) イクティノスIktinos が設計，カリクラテス kalikrates が施工を担当したと一般に言われる。しかし，R，力一 ペンターは, パルテノン神殿の再建工事について新しい 説を提出し，その中で, 旧パルテノンの再建がカリクラ テスを建築家として, 現在のパルテノンの再建がイクティ ノスを建築家として行われたとしている。

Vicent J.Bruno: The Parthenon and the the theory of classical form, The Parthenon edited by Vicent J. Bruno, 1974, W.W. Norton \& Company, Inc. p. 59. R. カーペンター著松島道也訳：パルテノンの建築家た ち, SD, pp.75-76.

3）周柱式神殿の成立に関する参照文献

A.W. Lawrence : Greek Arkitecture, The Pelican History of Art, Third edition, pp.88-98, 1973.

William Bell Dinsmoor: The Architecture of Ancient Greece, New York, pp. 36-68.

JJ. Coulton: Greek Arckitects at Work, London, pp. 30-50, 1977.

4）比例之調和に関する本邦の参照文献

森田慶一：ウィトルウィウスの建築論的研究, 森田慶一 建築論集，昭和 33 年.

元良勲：ギリシアに於ける建築的秩序原理の研究, 昭和 30 年, 私家版。

調和シュムメトリアとは sym-metros, 共に測られるとい う意味である。そして,その共約量がいくつであるかは幾 何学の方法と理論によって得られる」(ヴィトルヴィウス, I，1，4,4）。それは，モズルスの適用における技術の問 題である。森田同上書 pp. 48 49。シュムメトリアはモ ズルス, プロポルチオ (注 15) 参照), 幾何学的 (注 41) 参照）と結びついて技術的方法としての側面をもってい ることを重視したい。

5) 前 5 世紀後半の影刻家ポリュクレイトスは「カノーン」(規 準) を著わし，その中で理想的な人間像の比例が細かく 規定されていたと言う。ヴィトルヴィウスはポリュクレ イトス以外にも pracepta symmetriarum (均斉の訓へ) を著わした芸術家 9 人をあげており，その中のポルリス をピュタゴラス時代の人と推定している。

ディールス著・平田寛訳：古代技術, 創元科学叢書, pp. 17-18 (SD 選書で再販), 昭和 22 年.

6）森田曼一訳注：ウィトルウィウス建築書, 東海大学古典 叢書, 第三書第 1 章, p. 131 .

7) Dinsmoor 前掲書 p. 161.

8) 注 9 の Tobin の書 p. 379.

ウィットコウアの「モデュールから発展する有機的構造, 「均質尺度」には不通約性の数の余地がない」(中森戔宗 訳：ヒューマニズム建築の源流, 彰国社刊, p. 206, 1971), という考えに見られるように, 種々の幾何学の適用は, バルテノンが不通約性でできているという考えに立脚し ている。しかし，本研究は通約的グリッド法の適用とい う考えに立脚して「不通約性」を検討している。

9) J. J. Coulton: “Towards Under standing Doric Design : The Stylobate and Intercolumniations", BSA 69, pp.6186, 1974.

J. J. Coulton : Towards Understanding Greek Temple Design : General Considerations", BSA 70, pp.59-99,
1975.

R. Tobin: The Doric Groundplan, AJA 85, pp. 379427, 1981.

堀内清治：柱間寸法と基壇長さの分析方法 ドーリア式 神殿の設計技法に関する研究 (1), 日本建築学会論文報 告集第 349 号, pp. 101-112, 昭和 60 年 3 月.

10) Tobin 前揭書 p. 379 .

11) Coulton 前掲書 p. 61 (1974).

12) 平面数は two-dimentional number (又は plane number) の訳語（堀内による）。その数は,「例えば， $6 \times 16$ の平 面数は，幅で 6 点, 奥行きで 16 点で描かれる。この点描 で神殿平面を視覚的に表わすことは分かりやすい。初め の頃, 設計者が基壇上に平面数の点を描き，その点の数 が正面, 側面の柱数と一致していた。点の間隔は柱間で あった。(Tobin 前掲書 p. 381).

13）Coulton 前揭書（注 3), p. 53 .

14）堀内清治：「パルテノンの設計手順」地中海建筑の設計 技法の研究 (昭和 62 63 年度科学研究費補助金, 総合研 究 (A) 研究成果報告書, 課題番号 62302051, 平成元年 3 月, 研究代表者 熊本大学工学部堀内清治) pp. 276282. 昭和 63 年 9 月 10 日, 熊本大学堀内研究室が提唱し て「西洋建築史における設計技法に関するシンポジウム」 (於京都工芸瀻維大学) が開催された。同シンボジウムで 上記研究が発表された。

15）調和シュムメトリア (均整とも邦訳) をどのように解彩 するかは諸説がある。数的比例関係プロポーション(プ ロポルチオ）に対してシュムメトリアは美的統一原理, 美的価値観の概念としてみなされている。森田德一建築 論集（前揭書）pp.18-68, pp.131-145.

森田はシュムメトリアに対してプロポルチオ（比例）は 没洒值的概念であるとしている。森田同書 p. 60 .

パノフスキーは, プロポルティオは「尺度への換算」で, 建築技術の一方法であるとしている。アーウィン・パノ フスキー著中森義宗他訳 : 視覚芸術の意味, 岩涸美術社, p. 344, 1984.

シュムメトリアと比例アナロギア analogia (ana と logia の複合語, on the ratio の意味) との関係の考察は, 元良: 前揭書 pp. 60-70参照。

16）本文後述のように実測值はペンローズのものを利用した。 本文記載数值は隅柱間を除いて実測值が直接記述されて いるものを揭げた。従って，本文に記載がないちのは実 測値として揭載がないものである。また，複数の寸法に ついては煩雑になるため本文揭載を省略したが, その声 接明記の実測值は次の通りである。

$I=4.292 \mathrm{~m}$ (北・平均)

$D=1.905 \mathrm{~m}$ (西. 平均)

$D=1.905 \mathrm{~m}$ (北·平均)

$L=69.537 \mathrm{~m}$ (南)

以上，本文揭載の実測値も含めて 1 foot $=0.3048 \mathrm{~m}$ とし， て換算したものである。

隅柱間は，実測值がなく，東北隅の隅柱について基壇端 からその反対の靼柱面 (南側) が実測されているので, これより計算式 $15.356-\left(6.340-\frac{6.017}{2}\right)=12.0335 \mathrm{ft}=$ $3.668 \mathrm{~m}$ より算出した。ペンローズの，この実測値掦載 の方法はクールトンの第 3 公式を示唆するものである。 注 20 の F.C. Penrose の書参照。 
17） 1 ドリス尺 $=0.3275 \mathrm{~m}$ について堀内は側面列柱真々 APL (本研究ではPL と略記) $206 \frac{1}{4}$ 尺 $=67.552 \mathrm{~m}$ (南), $67.546 \mathrm{~m}$ (北) より 1 尺 $=0.3275248$ 又は $0.3274958=$ $0.3275 \mathrm{~m}$ を導いている。しかし，この導き方は，APL の尺寸法値が $206 \frac{1}{4}$ 尺と端数尺であるため, 端数尺の根 拠を示さない限り納得しがたい。堀内はパルテノン神殿 の設計法は身廊内法幅 30 尺よりスタートしたと述べてい るのであるから（注 14 の書参照），この30尺と実測値と の関係から 1 尺の寸法值を導くことが理論的に整合性を もっている。本文にも示したようにペンローズの身廊内 法幅（スタイロベート内法）の実測値が $9.8246 \mathrm{~m}$ (32. $233 \mathrm{ft}$ のメートル換算) であるから 1 尺 $=0.32749 \doteqdot$ $0.3275 \mathrm{~m}$ となる。ちなみに，オルランドスの身廊内法幅 の実測値 $9.815 \mathrm{~m}$ を 30 尺とすると 1 尺=0. $3272 \mathrm{~m}$ となる。 ディンズムアは前 409 の碑文断片より推定して 1 ドリス 尺 $=0.32685 \mathrm{~m}$ と推定している（注 3 の書 p. 161，n. 1)。 ディンズムアはもう1つの推定寸法值として 1 尺= $0.3272 \mathrm{~m}$ を示している(注 3 の書 p. 199, n. 3)。これは 上述のオルランドスの実測值からの推定寸法值と一致し ている。本稿では, 1 尺 $=0.3275 \mathrm{~m}$ が, 柱間や隅柱間お よびPLによく適合しているので，この方を採用し，実 測値もペンローズのものを採用した。オルランドスの実 測值で不思議なのは, 下記のように, 基壇実測值と, 神 室基壇実測値十周柱廊部分実測の合計値が一致していな ければならないのが幅（西）で $8 \mathrm{~cm}$, 奥行（北）で 6 $\mathrm{cm}$ の誤差があることである。

合計値 実測值

基壇幅：(東) $21.710+(4.5765+4.581)=30.8675 \mathrm{~m} \quad 30.88 \mathrm{~m}$

(西) $21.720+(4.568+4.589)=30.877 \mathrm{~m} \quad 30.961 \mathrm{~m}$

基增奥行: (南) $59.020+(5.227+5.262)=69.509 \mathrm{~m} \quad 69.503 \mathrm{~m}$

(北) $59.066+(5.210+5.275)=69.551 \mathrm{~m} \quad 69.609 \mathrm{~m}$

18）許容誤差は 1000 分の $1(10 \mathrm{~m}$ につき $1 \mathrm{~cm})$ 以内と筆者 は考えるが,ここでの許容誤差は基壇幅は東西両面で 8 $\mathrm{cm}$, 同奥行は南北両面で $10 \mathrm{~cm}$ の相違（オルランドスの 実測值による) をもっているので，幅では $4 \mathrm{~cm}$, 奥行き では $5 \mathrm{~cm}$ の誤差を差し引いて考える。

19）クールトンの平面公式（第 3 公式）は Coulton 前揭書 （注 9，1974）による。双正方形による計算式は本文参照。 クールトンの平面公式 $W=I_{w}\left(N_{W}+\frac{1}{5}\right), L=I_{L}\left(N+\frac{1}{5}\right)$ において $I_{W}=13 \frac{1}{8}$ 尺, $N_{W}=7, I_{L}=13 \frac{1}{8}$ 尺, $N_{L}=16$ を 代入すると，

$$
\begin{aligned}
& W=13 \frac{1}{8}\left(7+\frac{1}{5}\right)=\frac{105}{8} \times \frac{36}{5}=94 \frac{1}{2} \text { 尺 } \\
& L=13 \frac{1}{8}\left(16+\frac{1}{5}\right)=\frac{105}{8} \times \frac{81}{5}=212 \frac{5}{8} \text { 尺となる。 }
\end{aligned}
$$

双正方形の計算式によると $I_{A}=\frac{6}{7} I=\frac{6}{7} \times \frac{105}{8}=11 \frac{1}{4}$ とな る。

20） M. コリニョン著富永㥎一訳：パルテノン, 岩波書店, p. 38，1978 (改版) Dinsmoor 前掲書 Xix 参照：2人の 調查は, ディレッタント協会の後援の下でなされ, Artiquities of Athens として刊行された。その第 1 巻は 1762 年に, 第 2 巻 (Newton 編) は 1788 年に, 第 3 巻 (Reveley 編）は 1797 年に, 第 4 巻 (Joseph Woods 編) は 1816 年に出版された。

21) F.C. Penrose : An Investigation of the Principles of Athenian Architecture, published by the Society of
Dilettanti, London, 1888 (初版不詳).

同書のまえがきによると、スチュアートやリヴェットの 調查をより完全なものにすることにようて饬曲や傾斜 deviations の実態を解明し，その理論について論するこ とであった。同書によって各部寸法の比例関係の実態が 科学的に解明され, その成果がワトキス・ロイド, ハン ビッジ, ガードナーなどの説を生んでいる。

22）ワトキス・ロイドの主張はペンローズの著（注 21）に Appendix として揭載されている。

W. Watkiss Lloyd : On the General Theory of Proportion in Architectural Design, and Its Exemplification in Detail in the Parthenon, an abstract of a Paper read at the Royal Institute of British Architects, 13 th June 1859.

ワトキス・ロイドの主張はペンローズの調査結果に対す る最初の比例理論である。この理論についてペンローズ は, 問題を完全に解決したと絶賛している。

23) Jay Hambidge: The Parthenon and other Greek Temples, their dynamic symmetry, 1924, Yale University Press.

ハンビッジの解析はペンローズの資料にもとづいている。 一部自身で実測しで補っている。

ハンビッジと同じ頃, 同様な幾何的比例論者にエルンス ト・メーゼルがいる。彼は円周分割による幾何図形クラ イス・ジェオメトリーを提唱し，その図形を用いてパル テノン神殷の平面及び正面を $\sqrt{5}, \sqrt{5}+1, \sqrt{5}-1$ などの 適用として解析している。詳細な検討は別稿に譲るが， 円周の分割点・線のみの各部寸法の決定法は施工上誤差 が大きく無理のように思われる。

Ernst Moessel : Die Proportion in Antike und Mittelalter, Múnchen, 1926.

同上・第 2 巻, 1931 年, パルテ.ノン解析図は第 2 巻 pp. 24-34，Abb. 8,9,10,11，参照。

24） R.W. ガードナーの説は; 滝沢真弓著「バルテノンとピ タゴラス学派」(板垣鷹穂・堀口捨己編：建築様式論裳,

天文館, pp.67-98，1932）の紹介による。

R.W. Gardner : The Parthenon-its Science of Forms, (発行所不詳, 発行年 1925 は推定)。ガードナーの説も「厳 正無比なるペンローズの実測図に挟ったのである」(滝沢 同書 p. 90)。

25）Dinsmoor 前揭書 p. 161 本文及び注 1

同所においてドリス 1 尺を $0.32685 \mathrm{~m}$ として柱間 $13 \frac{1}{8}$ 尺, 基壇幅 $94 \frac{1}{2}$ 尺, 基壇奥行 $212 \frac{5}{8}$ 尺,オーダー総高 42 尺で設計されたと言う。パルテノンに関する資料は現 地アテネでの数年間の研究にもとづくもので，その考古 学的事実の堅さ, 明解さ, 精確さは秀れていると言われ る (Vicent J. Bruno 前揭書 p. 171)。

26) Coulton 前揭書 (1974), Table 2. クールトンの資料は 主にDinsmoor 前揭書（注 3）に基づいている。

27）堀内前掲書（注 14），

28）パルテノンに関する最近の概説書としてオルランドスの 著書がある。ANA $\Sigma$ T.K. OP $\Lambda$ AN $\triangle \mathrm{O} \gamma$ : H APXITETONIKH TOY $\Gamma A P \odot E N \Omega N O \Sigma$, A $\theta$ HNAI 1978. (A. K. Orlandos : H Architekonike toy Parthenon, Athenai, 1978) 同書は最近では最も詳しい概説書であろう。 同書は設計法に関して記述しているが,ハンビッジやメー ゼルの他, マイラール Mailard, ヴォルフ Wolff の研究 
を紹介している。これらは一連の幾何学的比例理論を形 成している。同書では, 数学的比例論やクールトンらの グリッド法は省かれている。

29) Hambidge 前揭書 p. Xiii .

L. D. Caskey の論考は Hambidge 前揭書序文として書か れたもの。

30) Watkiss Lloyed 前揭書（注 17）.

31) Hambidge 前揭書 p. Xiv.

32）Tobin は平面数を援用しているが, ワトキス・ロイドの 比例理論には言及していない。しかし，例えば，Tobin の $W \times L=6 \times 16 \rightarrow P_{W} \times P_{L}=5 \times 15$ という考え方はワト キス・ロイドの考え方と一致している。

33）テアイテトスの五で平方根について述べている。「共通の 単位で計りきることができない（すなわち通約できない） けれども，それの平方によって平面をもってすれば通約 できるという意味で，これを正方形の辺 (平方根)とし てしか取扱えないものとしました」。田中美知太郎訳：テ アイテトス，プラトン全集 2, 岩波書店, pp.193-196, 1974（上記引用 p. 195）

34）黄金分割を幾何学の命題として提起したのはユークリッ ドである。その命題は「ひとつの線分を大小に分かち, 小さい方の線分と全線分とで出来た矩形を，大きい方の 線分で出来た正方形に等からしめること」である。大小 の線分の比は $1: \frac{1+\sqrt{5}}{2}$ で表わされる。(柳宽著：黄金 分割,ビラミッドからル・コルビュジェまで, 美術出版社, 1965 年初版)

35 37) Hambidge 前揭書 $X V-X X i i$.

38) Rhys Carpenter : Dynamic Symmetry : A Criticism, American Journal of Archaeology, Second Series. Journal of the Archaeological Institute of America, Vol. XXV (1921), No. 1, pp. 18-36,

この批評は, Jay Hambidge : Dynamic Sgmmetry : the Greek Vase, Yale University Press, 1920 に対してなさ れた。

39）注 24 参照。

40）注 24 参照。ガードナーの説について滝沢は次のようにも 言っている。「ガードナー説については，しかしながら， 種々の不可解な事情が付随している。第 1 には彼自身が 一言もハンビッジに関説していない事だ。(中略)。第 2 には，彼に対する学会の冷淡な事だ。(中略)。彼と同国 の斯界の権威ハムリンが，ガードナーの出版後 2 年余を すぎてギリシア建築の比例論を発表した時においてさえ 一言もこの新説に関説しなかったとは，何と奇異な事で あるか。」

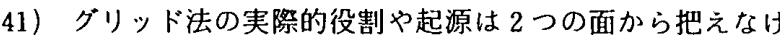
ればならないであろう。すなわち，語源的に土地測量を 意味する geometry（geo土地一metria 測昔の複合語，幾 何学という意味に転じた）と，単位の倍数（又は分数） による形態の構成を意味する symmetry (symmetrossym と metros〈metri，上記測量と同じ用語〉)とに共通 する実践的方法（芸術をも含む）を提供しているという ことである。 土地測量 geometryに関してへロドトスの「歴史」の中に， 「この王(セソストリス)はすべてのエジプト人に平等に， 等面積の土地を分け与え，この土地から生ずる物産を年 貢として納めるよう命じた。(中略)このようにして土地
測量術が発見され，これがギリシアに渡来したのだと思 われる」とある (中村幸四郎著：数学史，共立出版株式 会社, 基礎数学構座 12 , 昭和 31 年 p. 15)。ここていう等 面積の土地測量術はグリッド法を意味しているのは明ら かである。

古代ギリシアでは都市計画にグリッド法を採用している。 これをヒッポダモス式という。ギリシアの都市計画につ いては

ウィッチャリー著・小林文次訳：古代ギリシアの都市構 成，相模選書，昭和 55 年。

J.B. ワード=パーキンズ著北原理雄訳：古代壮リシア とローマの都市一古典古代の都市計画, 井上書店, 1984。 Junko Ito : The Site Planning of Greece and Rome, Theory and Practice of Architectural Planning in the Sancturies of Classical Antiquity, Kumamoto, 1988 (私 家版）を参照。

エジプト人は石や壁面に正方形格子の網目模样（グリッ ド）を描きこの雬目を利用して人間や動物を描写した。 ギリシア美術の原理はエジプト美術を起源ししているが, 古典期のギリシアでは人間の有機的機能を映しだす美的 観念性の領域に高められている。「美とは構成要嗉にある のではなく, 各部分の調和的比例……あらゆる部分と他 のあらゆる部分との比例の中にこそ美があるのだ」(ガレ ノスの「ヒュポクレイトスとプラトンの金言集」)パノフ スキ一前揭書（注 14）pp.67-102.

クールトンは, ギリシア神殿の平面はエジプト，メソポ タミアで発達した正方形グリッドを採用したと述べてい る。Coulton 前揭書 (注 3) p. 53 .

グリッドを用いて神殿の各部を決定してゆく造形法の治 練はギリシアの人体䧓刻の洗練と歩調を合わせている。 ギリシア美術の特色ともなる人体彫刻は古拙期に基盤が でき，前 5 世紀に入ってまもなく前 480 年頃を境にして 黄金時代を迎え，ギリシア的理想の人間像が確立する。 正しい均合と比例を通じて生まれる調和のある纹定感と, 純粋で明確な形式に整えられた折り目正しい造形性がそ の本質的性格となっている。この 5 世紀の美術活動の列 軸をなすのはフェイディアスで，パルテノン神殿の建設 事業にも総監督として関わっている。富永㥎一：古典期 の美術, 図説・世界文化史大系 ギリシア, 角川書店, pp. 169-195, 昭和 35 年初版。

42）グリッド法で美しい形態が造れるのかどうかが最大の難 問である。この難問に本研究は, 複数のグリッドの組放 合わせ, 特に完数尺単位グリッドと柱間単位グリッドと の組み合わせ法で考えた。

43）Coulton 前掲書（注 9，1974）による。平面公式はdesign rule for the stylobate propotion to the number of columns $W: L=C_{W}: C_{L}$ or $W: L=C_{W}:\left(C_{L}+1\right)$ and the stylobate size to the intercolumniation $W=I\left(N_{w}+\right.$ $k), L=I\left(N_{L}+k\right)$ の邦訳総称。

44）クールトン，堀内に従って本論文で使用する記号をまよ める。クールトンは注 9(1974 年) の書 p. 63, 堀内は注 9 の前揭書 pp. 108-109, 注 4 参照。

W : Width over stylobate 基壇幅(正確には基壇上面の幅) $L:$ Length over stylobate 基壇奥行（側面の長恕） OW : Over-all Width 基壇下面幅(階段クレピスを含む幅) $O L$ : Over-all Length 基壇下面奥行 (側面の長さ) $C_{w}:$ Number of Columns in Width 正面の柱数 
$C_{L}:$ Number of Columns in Length 側面の柱数

$I$ : Axial Intercolumniation 柱間寸法 (真々寸法)

(I)：柱間が正面と側面で異なる場合，最初に想定された 等間隔柱間寸法

$N$ : 柱間数, $C_{W}-1, C_{L}-1$ と同じ。 $N_{W}$ は正面柱間数, $N_{L}$ は側面柱間数

$P W$ : Axial Peristyle Width 正面左右の隅柱真々寸法

$P L:$ Axial Peristyle Length 奥行前後の隅柱真々寸法

$M$ : 完数尺の設計単位

45）Coulton 前揭書（注 3）pp.59-62. 17, 18 図に設計手順が 図解されている。

46）第 3 公式が成立しているもののうち側面を欠いているも のを除くと 25 棟で, そのうち 21 棟は基壇比 (OW : OL を含む) が成立し，その中で 7 棟は正面・側面の柱間が 異なっている。

47) Coulton 前掲書 (注 3) p. 63 .

48）同上書 p. 65.

49） Tobin 前掲書（注 9) 参照。 $X$ は original or canonical axial spacing の略号で求め方は次の注 50 参照。

50). $3 つ$ づループにおける $X$ の求め方は次の通りである。 Group I : Peristyle Expansion

I $a: a-1(a v . f r .-X)=b-1(a v . f l-X)$

I $b: a-1(a v . f r .-X)=b-1(X-a v . f l$.

Group II : Peristyle Contraction

II $a: a-1(X-a v . f r)=.b-1(X-a v . f l$.

II $b: a-1(X-a v . f r)=.b-1(a v . f l-X)$

Group III : Full Corner Contraction $a-1(X-a v . f r)=.b-1(X-a v . f r$.

$a v . f r$. (average frontial spacing), av. $f l$. (average flank spacing)は, $P W, P L$ の実測值を柱間数で割った 正面・側面の平均柱間寸法。Tobin 前揭書 chart IV 参照。 Group III の Full Corner Contractionは隅柱間のみ短縮 し，当初の等間隔柱間を保持する型式。

51）同上書 P. 380, p. 384 . note 23.

52）堀内前掲書（注 9）参照。堀内は柱間 $I$ を 2 分して $I=2$ $M$ として公式を求めている。従って, 正確には $\frac{k}{2} を K_{2}$

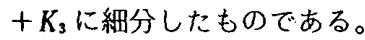

53）古代尺の換算は「W, $L, C_{w}, C_{L}$, 上り $I, S$ (隅柱真より 基增端までの距離, 筆者注) を計算し、これを古代尺に 換算した」「その際，考えられる尺数 $\times$ 尺度で計算された 柱間寸法や $S$ の長さが容認できる誤差範囲で実測値と一 致し， $\sum I_{W}+S_{w}, \sum I_{L}+S_{L}$ として算出される $W, L の$ 尺数 $\times$ 尺度が $\mathrm{mm}$ 単位の誤差で一致することを判断基準 とした」(一部筆者構成)。煀内同上書 p. 105.

54）壉内前揭書（注 14）

55）堀内研究室の伊藤重剛は設計手順を次のようにまとめて いる。「寸法計画をする場合, 基本設計, 実施設計, 詳細 設計の 3 つの段階がある。基本設計は完数を用い, 寸法 の比が簡単な整数比となるように完数尺単位のグリッド を設定する。」「次に実際の建物の実測図と実測寸法を検 討して, 寸法決定の過程というストーリを作る。」(筆者 構成)，注 14 の前掲書 P. 299 参照。

56) ヴィトルヴィウス書築書, 第 3,4 書参照。

57) エレア学派のパルメニデスParmenides(前 540-470 年頃) は, 究極の存在は球形であると考えた。门されど究極の限 界はあるものゆえ，まんまろき球の魂の如く，凡ゆる方
向において完結していて, 中心より凡ゆる方向において 均衡を得ている。」(山本光雄訳編：初期ギリシア哲学者 断片集, 岩波書店, p. 42, 1958)

その他参考文献, 田中美知太郎訳 : プラトン全集 4 パル メニデス，岩波書店, p. 36-40, 1975.

ヒルシュベルガー, 高橋憲一訳 : 西洋哲学史 [ I 古代], 理想社, p. 67 , 昭和 46 年。

プラトンの球形説は, 種山恭子訳 : プラトン全集 12 , ティ マイオス, 岩波書店, p. 38, 1975 を参照。

テイマイオスの建築論的研究として本邦の元良䡃前揭書 (注 4) pp.143-176がある。

58）双正方形については拙稿：古代ローマ・パンテォンの幾 何学的比例について一設計図法の考案とその適用に関す る研究, 日本建築学会計画系論文報告集, 第 356 号, pp.113-126, 昭和 61 , 当研究においてパンテオンの求厚 図法として，すなわち力学的図法として双正方形（双円 形接合図形) の幾何学図形が利用されていることを推定 した。

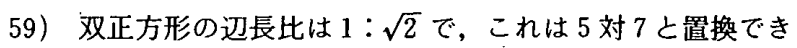
る。 $1.4142 \fallingdotseq 1.4$ である。このことは双正方形が $7 \times 7$ グ リッド四形に置換できることを示している。

60）古代ギリシアでは, 数学は幾何学的に発達した。そして, 数値は点を三角形や四角形に幾何学的に配列した図形で 研究された。これが本文で前述した平面数である。

野田哲夫著：科学世界史上巻, 丸善, pp. 75-79参照。

61）双正方形の $7 \times 7$ グリッド図形を用いた柱数決定法につい ては拙稿：双正方形グリッド図法による基壇比・柱数決 定法一ドリス式周柱神殿の設計法に関する研究, 日本建 築学会北陸支部研究報告, pp. 345-348, 1989 年及び, 同 名の拙稿（大同工業大学紀要, 第 25 巻, 1989 , pp. 171-181) を参照。

62） $7 \times 7$ グリッドから $9 \times 9$ グリッドをつくり；この両グリッ ド図形から幅 7 単位, 奥行 8 単位を選びだす。注 61) の 拙稿を参照。

63）柱数比が, $6 \times 13$, すなわち, $13=6 \times 2+1$ の場合, 基壇 比は, 6 対 13 ( 1 棟)， 6 対 13.5 (2 棟)，6対 14 (2 棟) OW: OLが 6 対 13 (4 棟) となっている。従って, 幅・ 奥行が $5 \times 12$ 単位に対して,おおよそ, ともに 1 単位, 1 単位と 1.5 単位, 1 単位と 2 単位が縮小される以前の大 きさを示している( $O W, O L$ は除く)。正面 6 単位を 5 単位に縮小した時, 側面は $\frac{13}{6}=2.2$ 単位縮小される。そ れで基壇比が 6 対 13 の例. (Assos, T. of Athena) では 正面柱間が大きい。基壇比が 6 対 13.5 の例 (Akragas, T. of 'Juno Lac') でも正面柱間が大きい。基壇比が 6 対 14 の例 (Akragas, T. of Concord) では正面・側面の柱 間が一致している $\left(I_{W}: 3.195 \mathrm{~m} ， I_{L}: 3.206 \mathrm{~m}\right) 。 6$ 対 14 は 3 対 7 で, $7=3 \times 2+1$ の関係式の形が $13=6 \times 2+1$ と 一致している。詳細は別稿で検討予定。

64）基壇の大きさはクールトンの第 3 公式で定まる。従って, $K_{2}$ 又は $K_{3}$ のどちらかが定まれば䨍柱の位置が決まる。 $K_{3}$ の決定には双正方形が適用される。本文及び拙稿： 九・九正方形格子システムによるパルテノン神殿の作図 一西洋建築史研究, 日本建築学会近畿支部研究報告集, pp. 857-60, 昭和 60 年. 参照。

65）基壇の高さは $1.85 \mathrm{~m}$ (6.058ft のメートル換算) で, 地 盤面までがこの 2 倍弱である。ペンローズ前揭書西正面 
Plate 9, chap II， sheet 3 参照。なお，本文の 10.5 尺は $4 I-3 M=7 \frac{1}{2}$ 尺の修正值。基壇の高さについては注 71 参照。

66）堀内前揭書（注 14）, p. 8

67）Penrose 前掲書 p. 115. 神室境壁決定の比例についてフ ラッグ Flag によると, 神室内法㽬：内陣内法奥行 $=9$ ： 14 の比で決定されたという。Ernst Flag : The Parthenon Naos; 1928, New York, p. 31, 69 参照。

68）注 58 の拙稿参照。

69) Penrose 前揭書 p. 16 シーマを加えて 1 柱間 $14.078 \mathrm{ft}$ としている。

70)フレッチャー建築史に $13.5^{\circ}$ と明記されている。Sir Banister Fletcher's A History of Architecture, Eighteenth Edition revised by J.C. Palmes, University of London, The Athlone Press, 1975. p.219. この角度は, Penrose 前揭書 plate 18, Chap. VI でも確認される。八 ンビッジは，「ペンローズのペディメントの高さを実測し
ていないが, その高さは柱軸間距離に等しいと推定でき

る」(注 18 の前揭書 p.11) と述べている。

71) Penrose 前揭書 p. 17. 同書 p. 17 の注 2 によると, $4 つ \sigma$ ステップの高さは, 下から $7: 14: 14: 15$ の比になって いる。(それぞれの実測値は $0.858,1.693,1.693$, $1.814 \mathrm{ft})$ 。

72）注 71 参照。

73）Watkiss Lloyd 前揭書（注 22）柱径と内法柱間を 4 対 5 と指摘している。Dinsmoor はこれを柱径・柱間比 4: 対 9 と言いかえている。Watkiss Lloyd は同書で, コ一ニスとアーキトレイヴ・フリーズ各成の比は 4 対 9 であ ると指摘している。

74) Carpenter 前揭書 (注 2) pp. 52-53

75）オリンピア・ゼウス神殿の設計手順は別稿で詳論予定で ある。

(1989 年 3 月 6 日原稿受理, 1990 年 1 月 29 日採用决定)

\section{英文要約 (Summary)}

The author reports as follows :

(1) First, a 4 unit $\times 9$ unit grit was set, with one unit equal to 15 doric feet in order to design the inner cella plan (Fig. 2).

(2) The grid (prepared in step 1) was extended into a grid comprising of a front width of 7 units and a depth of 15 units, in order to design the plan of the temple (Fig.9).

(3) The 7 unit front width involved in the grid (prepared in step 2) was divided into 8 equal units, and the depth into 18 units, based on a ratio of $4: 9$, thus obtaining another plan grid. So each unit measures $13 \frac{1}{8}$ doric feet which equals the axial intercolumniation on both fronts and flanks (Fig. 10).

(4) The axial intercolumniation between corner columns was reduced to $\frac{6}{7}$ of the original by using a $7 \times 7$ unit grid originating from a geometrical double-squared figure. This resulted in a distance of $11 \frac{1}{4}$ doric feet between corner columns (Fig. 11).

(5) The size of the stylobate was determined by proportionally reducing the grid (obtained in step 3 ) to geometrically position the four corners at $45^{\circ}$ (to the colonnade) to the point of intersection among the four corner column centers. The resulting front width of the stylobate was $94 \frac{1}{2}$ doric feet and the depth $212 \frac{5}{8}$ doric feet (Fig. 12).

(6) The size of the profile : $O W$ and $O L$, including stairs along the stylobate circumference, was determined by adding $\frac{15}{2}$ doric feet to the line running through the center of the colonnade on each side. A frontage $O W$ of $88 \frac{1}{8}$ doric feet and a depth of $206 \frac{1}{4}$ doric feet thus resulted.

(7) Using the grid (obtained in step 2), a grid 7 units wide $\times 3$ units high was set in order to prepare the facade (Fig. 13).

(8) Increased width for the intercolumnar unit was provided to above and below the top of the $3 \mathrm{rd}$ unit with the upper intercolumnar unit being equal to the pediment height. Subtracting the lower intercolumnar unit from the top of the 3 rd unit produced the column height of $31 \frac{7}{8}$ doric feet (Fig. 14).

(9) The diameter of the column (at the bottom) was $5 \frac{5}{6}$ doric feet which is equal to $\frac{4}{9}$ of the axial intercolumniation.

(10) The height of the entablature was determined by reducing the said 3 units into 4 units in relation to the 9 unit width of the stylobate. This reduced the overall height of 3 units to 42 doric feet from which the height of the column was subtracted, thus obtaining $10 \frac{1}{8}$ doric feet as the height of the entablature (Fig. 15). 